\title{
Regional precipitation estimations in Central America using the Weather Research and Forecast model
}

\author{
Tito Maldonado ${ }^{1 *}, 2$, Eric J. Alfaro ${ }^{2,3,4}$, Jorge A. Amador ${ }^{2,4} \&$ Anna Rutgersson $^{2}$ \\ 1. Centro de Investigaciones Geofísicas, Universidad de Costa Rica, 2060 San José, Costa Rica; \\ tito.maldonadomora@ucr.ac.cr; erick.alfaro@ucr.ac.cr; jorge.amador@ucr.ac.cr \\ 2. Department of Earth Sciences, Uppsala University, Villavägen 16, 75236 Uppsala, Sweden; \\ anna.rutgersson@met.uu.se \\ 3. Centro de Investigaciones en Ciencias del Mar y Limnología, Universidad de Costa Rica, 2060 San José, Costa Rica \\ 4. Escuela de Física, Universidad de Costa Rica, 2060 San José, Costa Rica
}

Received 09-III-2017. Corrected 03-VII-2017. Accepted 03-I-2018.

\begin{abstract}
Using the regional climate model WRF, and the NCEP-NCAR Reanalysis Project data as boundary and initial conditions, regional precipitation for Central America was estimated by means of the dynamical downscaling technique for two selected periods: January 2000 and September 2007. Four-nested domains, d01, $\mathrm{d} 02, \mathrm{~d} 03$ and d04 with a grid-resolution of $90 \mathrm{~km}, 30 \mathrm{~km}, 10 \mathrm{~km}$, and $3.3 \mathrm{~km}$ respectively, were configured over this region. The runs were reinitialized every 5 days with $6 \mathrm{~h}$ of spin-up time for adjustment of the model. A total of eight experiments (four per month) were tested in order to study: a) two important Cumulus Parameterization Schemes (CPS): Kain-Fritsch (KF) and Grell-Devenyi (GD); and b) the physical interaction between nested domains (one- and two-way nesting), during each simulated month. The modeled precipitation was in agreement with observations for January 2000, and also captured the mean climate features of rainfall concerning magnitude, and spatial distribution, such as the particular precipitation contrast between the Pacific and the Caribbean coast. Outputs of the coarse domains (d01, d02, and d03) for September 2007 revealed differences between experiments within the domains when a visual comparison of the spatial distribution was made. However, for the inner grid (d04), all the experiments, showed a similar spatial distribution and magnitude estimation, mainly in those runs using one-way nesting configuration. The results for the month of September differed substantially with the observations, which could be related to associated deficiencies in the boundary condition that do not reproduce well the transition periods from warm to cold ENSO episodes for the selected periods of study. In all the experiments, the KF scheme calculated more precipitation than the GD scheme and it was associated to the ability of the GD scheme to reproduce spotty but intense rainfall, and apparently, this scheme was reluctant to activate, showing frequent events of low intensity rain. However, when rainfall did develop, it was very intense. Also, the time series did not replicate specific precipitation events. Thus, the 5-days integration period used in this study was not enough to reproduce short-period precipitation events. Finally, physical interaction issues between the nested domains were reflected in discontinuities in the precipitation field, which have been associated with mass field adjustment in the CPS. Rev. Biol. Trop. 66(Suppl. 1): S231-S254. Epub 2018 April 01.
\end{abstract}

Key words: dynamical downscaling, regional models, reanalysis, cumulus parameterization schemes, Central America.

Climatic studies of the atmosphere require quality data that can be provided from either meteorological stations or outputs of Numerical Weather Prediction (NWP) models. Observations can be employed to study the climate and its variations over time in a specific region. Furthermore, observations can be used to validate the outputs and/or calibrate of NWP models. However, some requirements must be satisfied to use observed data such as long-time series, and, if it is possible, a good spatial resolution (station network). Besides that, quality control must be applied to assure reliability of such information. Unfortunately, in Central America, the lack of databases with such characteristics is one of the main complaints of 
the scientific community (Amador, 2008). To ameliorate this problem the use of mesoscale models rises as an alternative to study weather and climate of any particular region (Amador \& Alfaro, 2009). These models are also known as Regional Climate Models (RCMs) or Local Area Models (LAMs). LAMs are based on the physical and dynamical principles of the fluids (Warner, 2010). LAMs downscale the information generated by General Circulation Models (GCMs) (Trenberth, 2010), which have a resolution typically of $150-300 \mathrm{~km}$, to resolutions between $10-50 \mathrm{~km}$, or even less (Mass, Ovens, Westrick, \& Colle, 2002). This type of modelling is also known as dynamical downscaling (Amador \& Alfaro, 2009).

LAMs can be used to build weather prediction systems for climate research (Warner, 2010). Additionally, this technique captures topographical details that are not represented in GCMs, and produce information for regions with deficiency of measurements such as Central America. Yet, there is still uncertainty associated with the lack of climatic data for the verification of the models (Washington \& Parkinson 2005; Trenberth, 2010). Thus, it is recommended that an adequate knowledge of the climate of the region of interest be available to use LAMs (Amador \& Alfaro, 2009).

Experimentation using mesoscale models in Central America has been experiencing an increment in the last years (Hernandez et al., 2006; Maldonado, Alfaro, Maldonado-Mora, \& Alfaro-Martínez, 2010; Oglesby et al., 2016; Rivera \& Amador, 2009). In some of those studies the authors have pointed out that LAMs have shown a better performance simulating dynamical variables like the horizontal wind field, and thermo-dynamic variables such as temperature, but precipitation results have shown some discrepancies with observations in the region.

However, more work is needed to assess the performance of LAMs in reproducing the complex climate features in Central America, which are affected by both remote processes such as El Niño Southern Oscillation and the North Atlantic Oscillation (Enfield, 1996;
Giannini et al., 2000; Wang, 2007), and local processes due to complex topography, land use and coastlines (Hastenrath, 1967; Waylen et al., 1996; Peña \& Douglas, 2002). In this study we analyzed precipitation as a result of dynamical downscaling, using the LAM known as Weather Research and Forecast (WRF) (Skamarock et al., 2008) for Central America. Two months in specific years (January 2000 and September 2007) were simulated, which represent two distinctive phases of the precipitation regime in this area (Magaña, Amador, \& Medina, 1999). These months are distinctive of wet and dry seasons. Additionally, those specific years were important, due to the development of ENSO events as explained below. Comparisons between the Pacific and the Caribbean sides of Central America were made to determine whether the model was capable of reproducing the spatial distribution of precipitation during those months. Furthermore, due to the importance of the convective processes in local and regional scale circulations in the tropics, two cumulus parameterization schemes (CPS), were studied. Such CPSs have been often used to estimate convection implicitly in mesoscale models. Also, some issues found related to the physical interaction among nested domains were addressed.

\section{MATERIAL AND METHODS}

Precipitation was estimated employing dynamical downscaling techniques for January 2000 and September 2007 using the regional climate model WRF, and the NCEP-NCAR Reanalysis Project (Kalnay et al., 1996; Kistler et al., 2001) data as boundary and initial conditions. Four-nested domains were configured (Fig. 1A) over Central America. The runs were reinitialized every 5 days with $6 \mathrm{~h}$ spin-up time for adjustment of the model. Two cumulus convection schemes, Kain-Fritsch (KF) and Grell-Devenyi (GD) (Grell \& Dévényi, 2002; Kain, 2004), are tested for each simulated month. Also, the physical interaction among nested domains was examined, first by allowing the model to have feedback among nested 


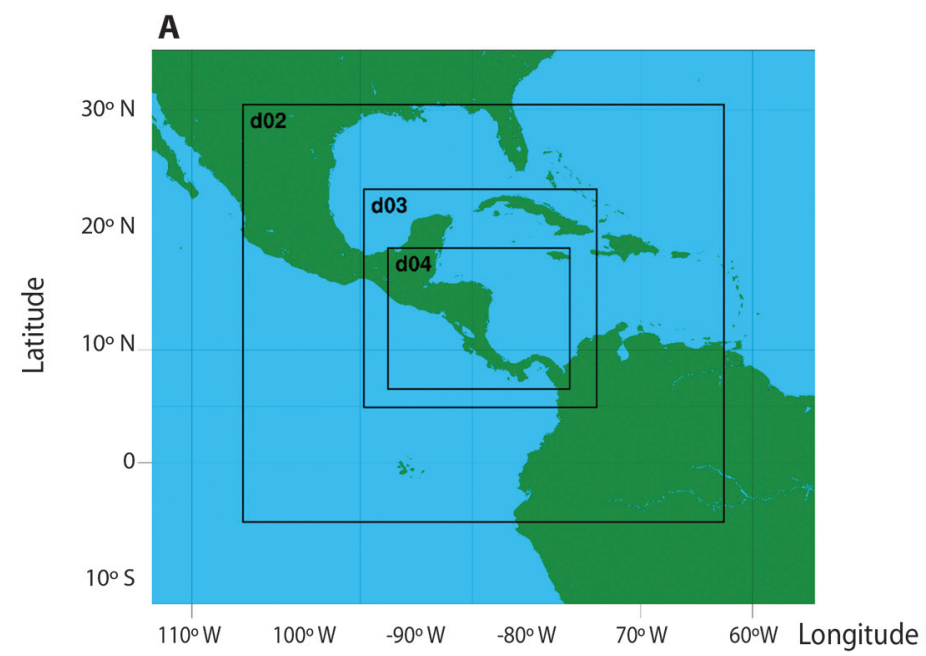

B

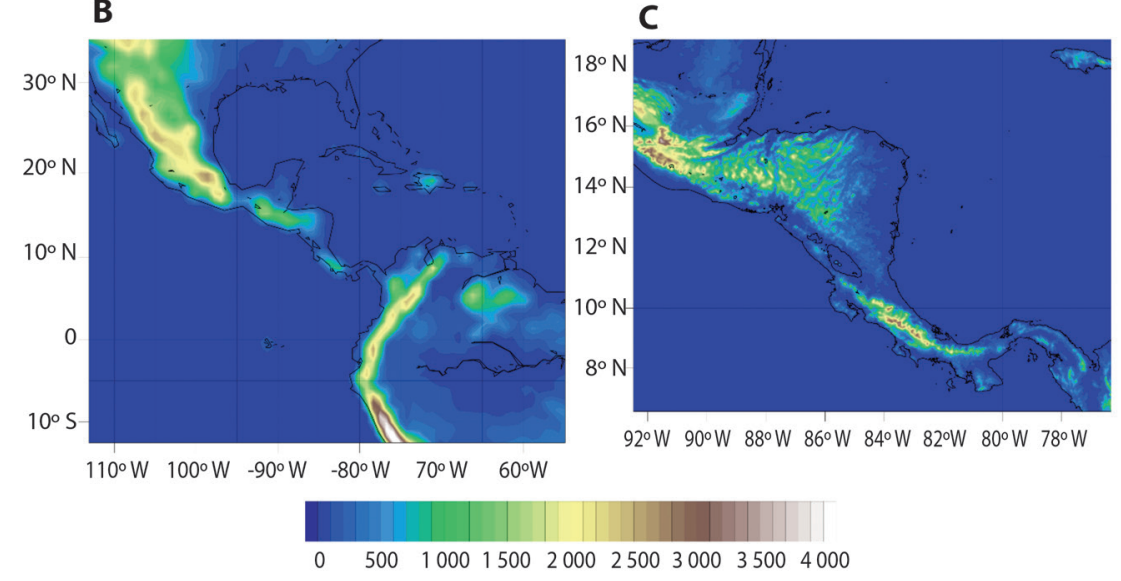

Fig. 1. Area coverage for the computational domains (grids); A: d01, d02, d03 and d04; and topography for the domains; B: $\mathrm{d} 01$ and $\mathbf{C}: \mathrm{d} 04$.

domains (two-way nesting), and second, by allowing calculation just in one direction, from the outer to the inner domain (one-way nesting). For comparison, daily precipitation data from gauge stations were divided in three important regions (Fig. 2) according to local precipitation structures observed, and to the quality of the data reported by the stations during each month.

On the Weather Research and Forecast (WRF): The mesoscale model WRF version 3 (Skamarock et al., 2008) was used; this
Numerical Weather Prediction (NWP) model is designed and used for both research and operational applications. This model has some important characteristics such as: (a) a fully comprehensive set of equations; (b) Euler non-hydrostatic with a run-time hydrostatic option available; (c) prognosis variables such as horizontal velocity $(\mathrm{u}, \mathrm{v})$ in Cartesian coordinates, vertical velocity (w), and perturbation of potential temperature; (d) the vertical coordinate system is terrain-following and dry hydrostatic-pressure with vertical grid stretching is allowed; (e) the model assumes a constant 


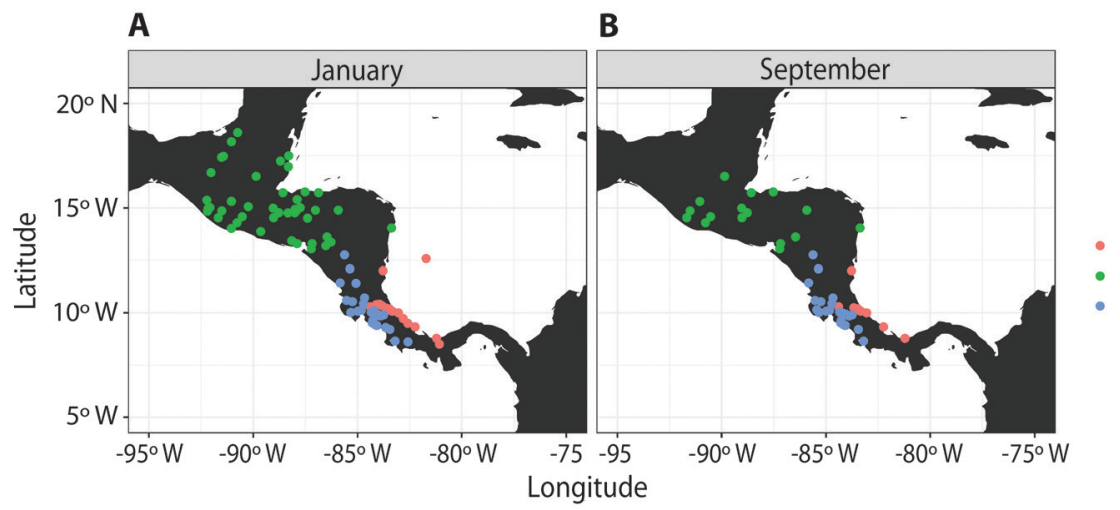

Fig. 2. Spatial distribution of meteorological stations deployed in Central America during A: January 2000 and B: September 2007. Pink dots represent stations located in southern Caribbean, 17 in A, and 9 in B; blue dots are stations in south Pacific, 27 in A, and 22 in B; green dots are stations in northern Central America, 48 in A, and 17 in B.

pressure surface on the top; and (f) the horizontal grid uses the Arakawa C-grid staggering set-up.

The WRF model allows performing one-, two-way interactive and moving nests setups. For physics, it employs microphysics schemes ranging from simplified to sophisticated (mixed-phase) physics suitable for processes studies and NWP. The WRF model also uses cumulus parameterization with adjustment and mass-flux schemes for mesoscale modeling. Multi-layer land surface models from simple thermal model to vegetation and soil moisture models are used for surface physics. Local K schemes (Hong \& Pan, 1996) are used to parameterize the physics in the planet boundary layer. Longwave and shortwave schemes with multiple spectral bands and a simple shortwave scheme are used, being suitable for climate and weather prediction applications.

Experimental design: To study the WRF performance in downscaling applications, two months: January 2000 and September 2007 were chosen in this study to simulate regional precipitation in Central America. These months have some particular climatological features interesting to study. In January the dry season usually has already started in the Pacific slope, whereas the Caribbean side in contrast, shows wet conditions (Taylor \& Alfaro, 2005;
Amador, Alfaro, Lizano, \& Magaña, 2006; Amador et al., 2016). Contrary, in September, the Pacific coast is wetter than the Caribbean coast. Furthermore, the month of September has a high probability of occurrence of extreme precipitation events (Alfaro et al., 2010; Maldonado \& Alfaro, 2010, 2011; Maldonado, Alfaro, Fallas-López, \& Alvarado, 2013).

The meteorological conditions reported during the two months simulated here are described as follows. Through January 2000, the meteorological report stated that cold episode (La Niña) conditions prevailed in the Pacific, continuing the long-running episode that began in mid-1998. This cold episode was reported as strongest in January 2000 during the winter season in the Northern Hemisphere (Lawrimore et al., 2001). Locally, in Central America, mean conditions for La Niña events were reported: maximum temperatures below normal values, and surplus of precipitation over the Caribbean side. According to the National Meteorological Service of Costa Rica (Instituto Meteorológico Nacional [IMN], 2004), during January 2000, migrating high pressure systems $(>1030 \mathrm{hPa}$ ) from the Gulf of Mexico to the Caribbean Sea produced trade winds with moderate to high velocities. Cold air intrusion from North America during this month provoked a decrement in maximum temperatures (about $3{ }^{\circ} \mathrm{C}$ ) in San Jose, Costa Rica. The southern 
Caribbean part of Central America was the most affected by the intrusion of cold fronts that reached such latitudes. For instance, on the Caribbean coast of Costa Rica, the observed monthly accumulated precipitation was 468 $\mathrm{mm}$, which is $100 \mathrm{~mm}$ greater than the monthly mean value $(308 \mathrm{~mm})$. While on Pacific side, the monthly accumulated recorded by the stations was catalogued as normal.

In the second case, the year 2007 was characterized by a transition to La Niña event, developed until August, and resulted in suppressed convection near the date line by early June. The Atlantic hurricane season was near normal and slightly more active in 2007 than in 2006. However, tropical cyclone activity was significantly below average in the eastern North Pacific (Levinson \& Lawrimore, 2008). During the month of September, the National Meteorological Service of Costa Rica (Instituto Meteorológico Nacional [IMN], 2007) reported extreme precipitation events mainly in the central and northern part of the country. The monthly accumulated rainfall was of the order of $400 \mathrm{~mm}$ in this area where several natural disasters like floods were reported. On the other hand, stations located in the Pacific and Caribbean side of the country reported rainfall below normal. From nine tropical cyclones developed in the Caribbean basin only three became hurricanes, of which only Felix was an intense hurricane. Nevertheless, this hurricane had no effect over the country due to an anticyclone circulation and a disorganized ITCZ.

Domain configuration: Figure 1A shows the four-nested domains configuration upon Central America used in this study. The selected resolutions from the outer to the inner domain were $90,30,10$ and $3.3 \mathrm{~km}$. The size and resolution of the grids in the outer domain (d01) were chosen to decrease the interpolation effects from the boundary conditions (Warner, 2010). This domain was located over the Easter Tropical Pacific (ETPac), the Caribbean Sea, and the Gulf of Mexico (Fiedler \& Lavín, 2006). The entire region is often referred as the Intra-Americas Sea (Amador, 2008). This area encloses an important part of both oceans and is called the Western Hemisphere Warm Pool (Wang \& Enfield, 2001, 2003; Enfield, Lee, \& Wang, 2006; Lee, Enfield, \& Wang, 2007; Wang, Lee, \& Enfield, 2008). The Sea Surface Temperature (SST) of this oceanic region has an important influence in the timing and duration of the precipitation over Central America (Enfield \& Alfaro, 1999; Alfaro, 2000, 2007; Maldonado \& Alfaro, 2010, 2011; Maldonado et al., 2013). Other mesoscale phenomena within this domain are the cold air intrusions from the northern hemisphere due to frontal zones (Schultz et al., 1997; Schultz, Bracken, \& Bosart, 1998; Zárate-Hernández, 2013, 2014), and the easterly waves, which are important mechanisms for rainfall production during January and September, respectively (Amador et al., 2006, 2016).

The domains $\mathrm{d} 02$ and $\mathrm{d} 03$ were selected to smooth the information flowing from the outer to the inner domain (d04). Besides, this configuration was aimed to avoid some topographical forcing at the boundaries, and it was aimed to enclose the whole Central America region in a domain with a resolution of $3.3 \mathrm{~km}$. Figure 1 also shows the topography in outer (Fig. 1B) and inner (Fig. 1C) domains. Also, 28 vertical levels were configured in the mesoscale model.

The NCEP/NCAR Reanalysis Project data (Kalnay et al., 1996; Kistler et al., 2001) was used as boundary and initial condition. This reanalysis data has a horizontal triangular truncation of 62 waves, equivalent to a horizontal resolution of $2.5^{\circ}(\mathrm{km})$ (latitude by longitude), 28 sigma vertical levels, and an output frequency of $6 \mathrm{~h}$. Simulations were reinitialized every five days rather than attempting continuous simulations, following the results from Qian, Seth, \& Zebiak (2003), and Rivera \& Amador (2009), in which they showed that short period simulations, in contrast to continuous runs, have a smaller error in precipitation compared to observations. Furthermore, $6 \mathrm{~h}$ of spin-up time for adjustment of the model was considered after Wang \& Seaman (1997), which found that during the first $6 \mathrm{~h}$ the model showed an inability to handle precipitation forecasts. 
Physical Parameterizations: domains $\mathrm{d} 01, \mathrm{~d} 02$ and $\mathrm{d} 03$ use CPS, the inner grids (d04) only uses an explicit convection scheme. The latter was following the recommendations given by Molinari \& Dudek (1992). They found that for a grid spacing that fell below 5-10 km, an explicit scheme was enough to represent cumulus convection, but it could not provide a general solution for resolutions above $10 \mathrm{~km}$. A hybrid approach, allowing explicit and implicit schemes, worked better for grid spacing greater than $10 \mathrm{~km}$ (mesoscale models), since this method separated convectivescale motions from the slow growth, fallout, and phase changes of detrained hydrometeors that produced mesoscale organization of convection. The cumulus schemes tested were GD (Grell \& Dévényi, 2002), and KF (Kain, 2004). These schemes have been widely used in other studies such as Wang \& Seaman (1997); Mapes, Warner, Xu, \& Negri (2003); Bukovsky \& Karoly (2009); Rivera \& Amador (2009); Rivera \& Amador (2009); Maldonado \& Alfaro (2010).

GD introduced an ensemble cumulus scheme in which multiple cumulus schemes and variants were run within each grid box and then the results were averaged to give feedback to the model. The schemes were all mass-flux type schemes, but the updraft and downdraft entrainment and detrainment parameters, and precipitation efficiencies differed. These differences in static control were combined with differences in dynamic control, which was the method to determine cloud mass flux. The dynamic control closures were based on convective available potential energy (CAPE), lowlevel vertical velocity or moisture convergence.

The KF scheme was based on Kain \& Fritsch $(1990,1992)$, but has been modified based on testing within the Eta model. It utilized a simple cloud model with moist updrafts and downdrafts, including the effects of detrainment, entrainment, and relatively simple microphysics. The current KF scheme differed from the original KF scheme in the following ways: (a) a minimum entrainment rate was imposed to suppress widespread convection in marginally unstable, relatively dry environments; (b) shallow (non-precipitating) convection was allowed for any updraft that does not reach minimum cloud depth for precipitating cloud, varying as a function of the cloud-base temperature; (c) the entrainment rate was allowed to vary as a function of low-level convergence; and (d) downdraft changes such as the source layer, mass flux as a fraction of updraft mass flux at the cloud base, and detrainment were specified to occur in updraft source layer and below.

Other physical parameterization schemes considered in this research were: (a) the WRF single-moment 6-class (WSM6) was chosen for microphysics. This scheme included graupel and associated processes. It uses a new method for representing mixed-phase particle fall speeds for the snow and graupel particles by assigning a single fall-speed to both that is weighted by the mixing ratios, and applying that fall-speed to both sedimentation and accretion processes (Dudhia, Hong, \& Lim, 2008); (b) for shortwave radiation the MM5 scheme is used. This scheme was based on Dudhia (1989) which has a simple downward integration of solar flux, accounting for clear-air scattering, water vapor absorption, and cloud albedo and absorption; (c) Land-Surface physics used the Pleim-Xiu LSM scheme (Pleim \& Xiu, 1995; Xiu \& Pleim, 2001), includes a 2-layer forcerestore soil temperature and moisture model. The top layer was taken to be $1 \mathrm{~cm}$ thick, and the lower layer was $99 \mathrm{~cm}$. This scheme featured three pathways for moisture fluxes: evapotranspiration, soil evaporation, and evaporation from wet canopies; (d) Surface physics scheme employed similarity theory (MM5), and it used stability functions to compute surface exchange coefficients for heat, moisture and momentum; and (e) Planetary Boundary Layer (PBL) uses the Medium Range Forecast Model (MRF) described by Hong \& Pan (1996). It employed a counter-gradient flux for heat and moisture in unstable conditions. It used enhanced vertical flux coefficients in the PBL, and the PBL height was determined from a critical bulk Richardson number. It handled vertical diffusion with an implicit local scheme, 
and it was based on the local Richardson number in the free atmosphere. The so-called first-order local- $K$ approach following Louis (1979) was used for boundary layer as well as the free atmosphere.

Finally, runs allowing no interaction (oneway nesting) or interaction (two-way nesting) among domains were performed. Table 1 shows a summary of the experimental design in this research.

Model verification: daily precipitation data from meteorological gauge-stations gathered by the Center for Geophysical Research (Centro de Investigaciones Geofísicas, CIGEFI, in Spanish), University of Costa Rica, were used for verification of the model outputs. Such database has been widely used in other studies such as Maldonado \& Alfaro (2010, 2011); Quesada-Montano (2011); and Maldonado et al. (2013). After quality control, by considering only stations with at least $60 \%$ of the data during each month, a total of 92 and 48 stations were left in January and September, respectively. These stations were divided in three regions in order to capture important precipitation structures (Fig. 2). Notice the deficit of stations in September 2007 compared to January 2000. This reduction in number of stations was also noted in Quesada-Montano (2011, her figure 2 ), where she explained that this reduction was produced for two reasons: 1) A number of stations of the network have been out of service, and 2) obtaining reports from some of these stations has been increasingly difficult.
For each model domain, the nearest grid points to station were compared. The same statistical methods described in Pierce, Barnett, Santer, \& Gleckler (2009) for model evaluation were used here. These authors evaluated a broad spectrum of metrics based on temperature and precipitation for a selection of models. In the present work, only precipitation was analyzed. The following metrics were applied to the spatial distribution.

Let the model output be $m$ and the observations be $o$. The mean squared error (MSE)

$$
\operatorname{MSE}(m, o)=\frac{1}{N} \sum_{k=1}^{N}\left(m_{k}-o_{k}\right)^{2}
$$

where $\mathrm{k}$ varies from 1 to a total of $N$ spatial points. Then, a dimensionless spatial skill score $(S S)$ is defined by normalizing MSE by

$$
S S=1-\frac{\operatorname{MSE}(m, o)}{\operatorname{MSE}(\bar{o}, o)},
$$

where the overbar on $o$ indicates its spatial mean i.e. the monthly accumulated average for all statistics. Thus, a model output identical to observations has a skill score of 1 , a completely featureless, uniform pattern yields a spatial skill score of 0 and a negative score occurs when the observed mean is better than the model output. The skill score $S S$ can be decomposed as:

$$
S S=r_{m, o}^{2}-\left[r_{m, o}-s_{m} / s_{o}\right]^{2}-\left[(m-o) / s_{o}\right]^{2}
$$

where $r_{m, o}$ is the product moment spatial correlation coefficient between the model and observations, and $s_{m}$ and $s_{o}$ indicate the sample

TABLE 1

List of experiments done with WRF using different Cumulus Parameterization Schemes. Cumulus parameterization schemes, nesting configuration and notation used for the experiments. CPS = cumulus parameterization scheme

\begin{tabular}{cccc} 
CPS $^{1}$ & Nesting & Month & Experiment ID \\
Kain-Fritsch & Two-way & January 2000 & KF2WJ00 \\
Kain-Fritsch & One-way & January 2000 & KF1WJ00 \\
Grell-Dévényi & Two-way & January 2000 & GD2WJ00 \\
Grell-Dévényi & One-way & January 2000 & GD1WJ00 \\
Kain-Fritsch & Two-way & September 2007 & KF2WS07 \\
Kain-Fritsch & One-way & September 2007 & KF1WS07 \\
Grell-Dévényi & Two-way & September 2007 & GD2WS07 \\
Grell-Dévényi & One-way & September 2007 & GC1WS07 \\
\hline
\end{tabular}


standard deviation of the model and observations, respectively. The right-hand terms are described as follows: the first term is the square of the correlation, and is a measure of the proportion of the variability that is accounted for by the forecast. The second term is the conditional bias, and expresses the degree in which a spatial regression between the model and observations has a slope that differs from the unity, that is, this term describes a model tendency to over- or under-predict excursions (Murphy, 1988). The third term is the square of the unconditional bias, which is proportional to the square of the mean error normalized by the standard deviation of the observations. The sense of this decomposition is that the skill starts from the square of the correlation, and is penalized for any conditional or unconditional bias.

In order to determine if the curves (observations and model outputs) came from the same distribution (null hypothesis); a Kolmogorov-Smirnov test (KS) (Wilks, 2011) was performed. According to Table 2, in inner grids of the GD2WJ00 and KF1WJ00 experiments the null hypothesis was accepted at the $95 \%$ of confidence level, but not accepted in the other two cases (KF2WJ00 and GD1WJ00).

\section{RESULTS AND DISCUSSION}

Figure 3 shows the monthly mean of monthly total precipitation from reanalysis data for both months. January 2000 shows two important high precipitation regions (Fig. $3 \mathrm{~A})$. The first one is over the Amazon River, and towards the center of South America. The second one is located close to the western coast of Colombia, where the Chocó low-level jet is develops (Poveda \& Mesa, 2000). According to Poveda \& Mesa (2000), the last region is known as the rainiest area of the Americas, and arguably in the world. In this zone, normally during the quarter December-January-February the average of precipitable water is $45-50 \mathrm{~mm} /$ day (See their Fig. 5). In September 2007 (Fig. 3B) only a maximum of precipitation is located over the Pacific coast. This maximum

TABLE 2

Two-sided Kolmogorov-Smirnov test between observations and model outputs of January 2000 monthly total precipitation profiles in Fig. 8. Numbers in bold are within the $95 \%$ of confidence level. In parenthesis are the p-values

\begin{tabular}{cllll} 
Domain/Experiment & KF2WJ00 & KF1WJ00 & GD2WJ00 & GD1WJ00 \\
D01 & $\mathbf{0 . 3 5 ( 0 . 0 7 )}$ & $0.42(0.01)$ & $0.46(0.00)$ & $0.50(0.00)$ \\
D02 & $\mathbf{0 . 3 1 ( 0 . 1 4 )}$ & $\mathbf{0 . 3 5 ( 0 . 0 7 )}$ & $\mathbf{0 . 3 1 ( 0 . 1 4 )}$ & $0.65(0.00)$ \\
D03 & $\mathbf{0 . 3 5 ( 0 . 0 7 )}$ & $\mathbf{0 . 2 3 ( 0 . 4 4 )}$ & $\mathbf{0 . 2 3 ( 0 . 4 4 )}$ & $0.58(0.00)$ \\
D04 & $0.38(0.03)$ & $\mathbf{0 . 1 9}(\mathbf{0 . 6 7})$ & $\mathbf{0 . 2 3 ( 0 . 4 4 )}$ & $0.42(0.01)$ \\
\hline
\end{tabular}

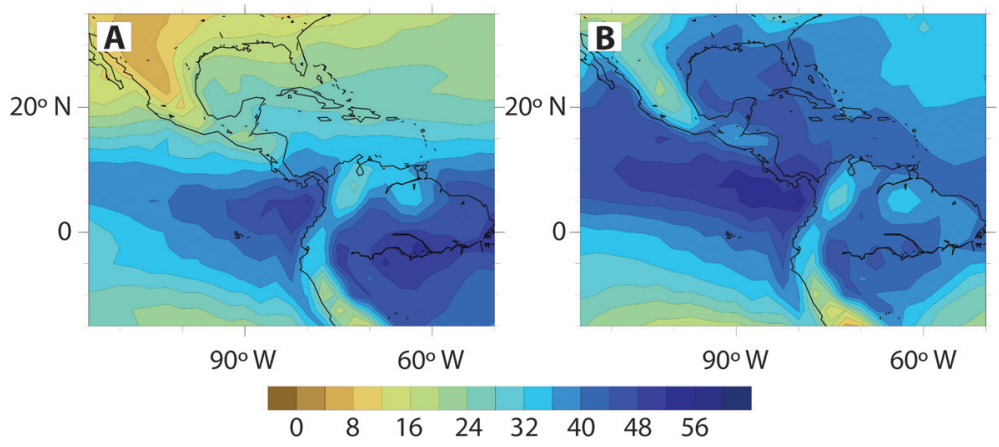

Fig. 3. NCEP/NCAR daily average of precipitable water for A: January 2000, and B: September 2007. The shades are spaced each $4 \mathrm{~kg} \mathrm{~m}^{-2}$. 

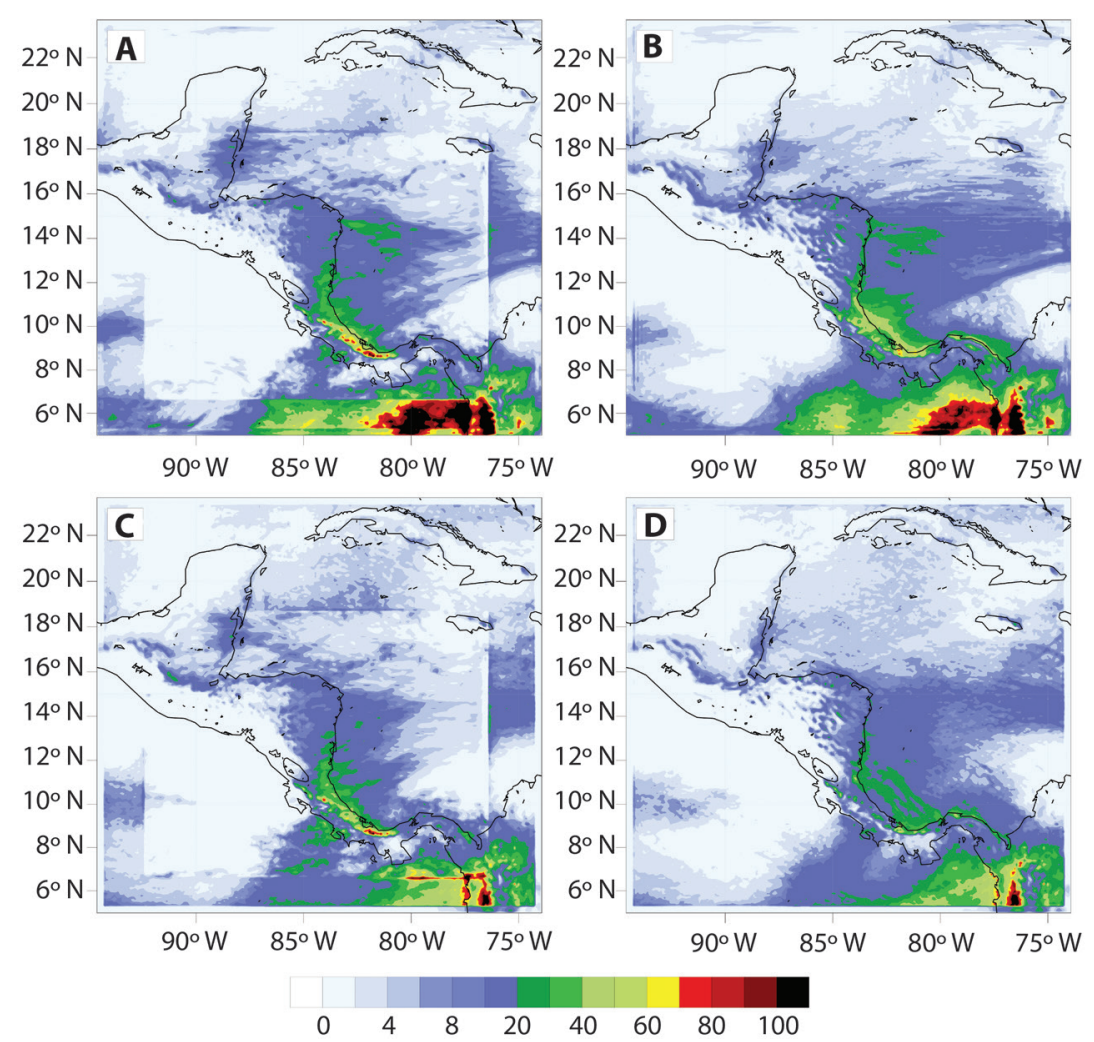

Fig. 4. Average daily precipitation rates for domain $3(10 \mathrm{~km})$ for January 2000 using different experiments: scheme KainFritsch (KF) in $\mathbf{A}$ and $\mathbf{B}$, scheme Grell-Devenyi (GD) in $\mathbf{C}$ and $\mathbf{D}$ and using two-way nesting $\mathbf{A}$ and $\mathbf{C}$ and one-way nesting $\mathbf{B}$ and $\mathbf{D}$ for each scheme. See text for explanation of discontinuities in Fig. 4 A, C.

of precipitation can be related to relative position of the Inter-tropical Convergence Zone (ITCZ) (Srinivasan \& Smith, 1996; Amador et al., 2006, 2016), which during La Niña can be located even further north (Hidalgo, DuránQuesada, Amador, \& Alfaro, 2015; QuirósBadilla \& Hidalgo-León, 2016). The reanalysis results are compared with the outer domain in both experiments.

January 2000: Figure S1 shows the daily average rate of precipitation during January 2000 estimated for domain d01 $(90 \mathrm{~km})$. The experiments captured the spatial distribution of precipitation in this month as in the reanalysis. However, the results of Fig. S1 also show that the maximum estimated over the Pacific coast is larger than the one over the Amazons.
The maximum amount of rainfall calculated in KF2WJ00 (Fig. S1A), is larger $(80 \mathrm{~mm} /$ day) than the amount calculated in KF1WJ00 (Fig. S1C) $20-60 \mathrm{~mm} /$ day. The experiments GD2WJ00 (Fig. S1C) and GD1WJ00 (Fig. S1D) detected also this maximum, but with less intensity, 20-60 $\mathrm{mm} /$ day in each experiment. Another important feature of Fig. S1 is the relative maximum of rainfall present over the Caribbean coast of Nicaragua and Costa Rica, and the drier conditions detected in the Pacific side. Such a contrast has been already documented, and it is one of the major climatic features of the precipitation during the boreal winter (Amador et al., 2006). Among the dynamical mechanisms that explain that pattern is the interaction between northeasterly 


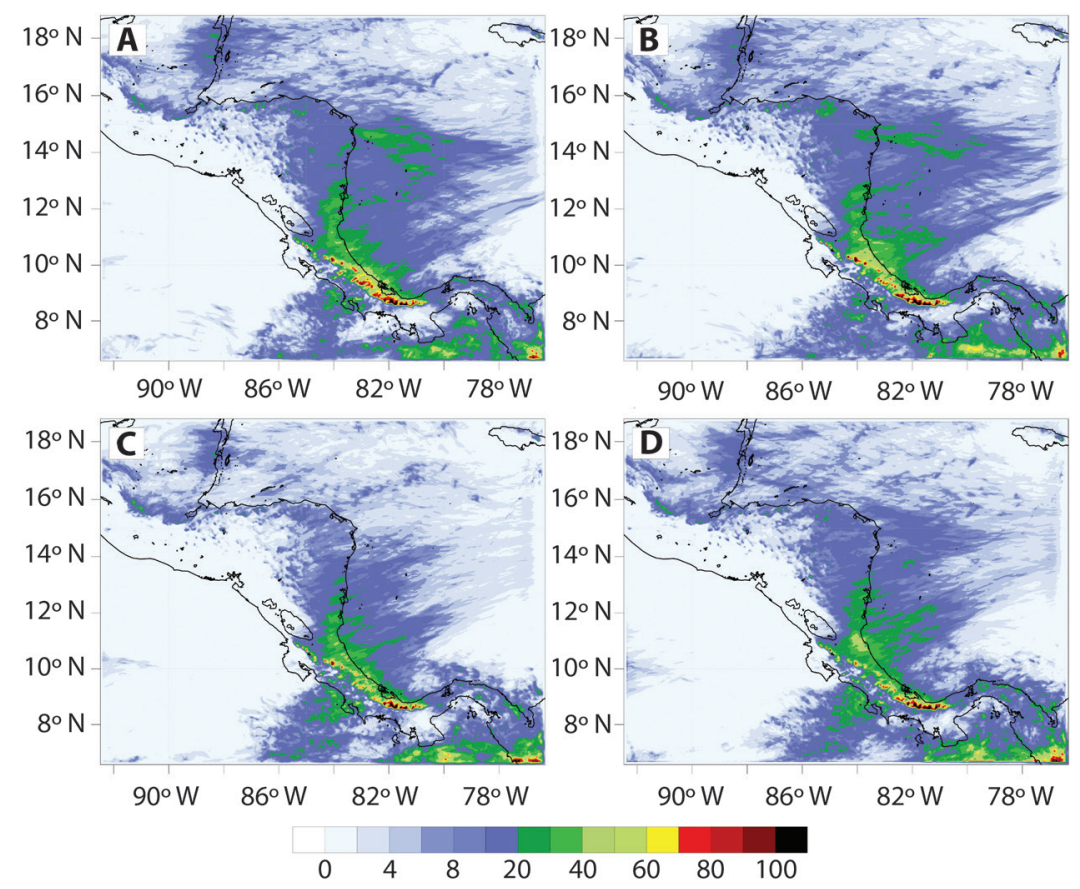

Fig. 5. Average daily precipitation rates for domain $4(3.3 \mathrm{~km})$ for January 2000 using different experiments: scheme KainFritsch (KF) in $\mathbf{A}$ and B, scheme Grell-Devenyi (GD) in $\mathbf{C}$ and $\mathbf{D}$ and using two-way nesting $\mathbf{A}$ and $\mathbf{C}$ and one-way nesting $\mathbf{B}$ and $\mathbf{D}$ for each scheme.

cold winds intrusions during this month and the topography. In general, KF2WJ00 (GD1WJ00) predicts more (less) rainfall than the rest of experiments. Also, in Fig. S1 the ITCZ is located in between $5-15^{\circ} \mathrm{N}$, which during this month is located in its southern position.

Fig. S1 also shows two issues that the model has at the domain boundaries. The first one is the relaxation zone near the boundaries. This pattern was also noted in Bukovsky \& Karoly (2009). The second one is observed in experiments KF2WJ00 and KF1WJ00 (Figs. S1A and S1B respectively). Both experiments show unrealistic results approximately between $10-12^{\circ} \mathrm{S}$ and $75-70^{\circ} \mathrm{W}$. Stensrud Gall, Mullen, \& Howard (1995), and Gochis, Shuttleworth, \& Yang (2002), found using an older version of KF scheme the same non-physical spots, and they explain that such unrealistic intense bands of precipitation are located right at the upwind boundary where unstable air from the coarse domain enters the finer-grid domain. There is an inflow at this boundary, and the thermodynamic structure of the imported atmosphere is largely determined by the structure on the coarse domain, that in this case, NCEP/NCAR reanalysis uses the Arakawa-Schubert convective scheme developed by Pan \& Wu (1994). Also, notice that this region is close to high mountains, the Andes, which could intensify these instabilities due to orographic effects.

Figure S2 and 4 show the average daily rates of precipitation in grids 2 and 3, respectively. Since these grids were used to smooth the information flow from the outer to the inner domain, only some general aspects will be commented on them. The experiments KF2WJ00 (Figs. S2A and 4A) and KF1WJ00 (Figs. S2B and 4B), showed the largest rainfall amount calculated by the model, consistent with the previous results in the outer domain. Maximum over the west coast of Colombia, and the Caribbean side of south Central America were detected in both grids, but notice that 
the amount differed in each case. From these graphs, one can see that GD2J00 (Figs. S2C and 4C) and GD1WJ00 (Figs. S2D and 4D) cases do not reproduce the same intensity for these maxima, especially over the continental part of Nicaragua and Costa Rica.

Discontinuities in the precipitation field were found in the experiments KF2WJ00, and GD2WJ00 of domains 2 and 3 (Figs. S2 and 4 , respectively). In these domains, a hybrid convection scheme (explicit and implicit) was employed. These discontinuities coincided with the boundaries of the inner domain, in which only an explicit convection scheme was allowed. In contrast, feedback among the nested domains was allowed for the domains 2 and 3. Some irregularities in the precipitation field were also found first by (Warner \& Hsu, 2000) using the MM5 model, and lately by Bukovsky \& Karoly (2009). The latter gave evidence that there are physical interactions issues present in the convection schemes, which are not model dependent. Such discontinuities appeared to be due to the mass adjustment in inner grids, which are influenced by the propagation of gravity waves across their boundaries, causing abnormal attenuation or increase convection (Warner \& Hsu, 2000).

One can see for the inner grids (Fig. 5), that a rainfall maximum extended over the
Caribbean side, specifically in northern Panama, the east coast of Costa Rica, and decreasing towards southern Nicaragua. Nevertheless, the position and amounts of this maximum differed considerately between the experiments. The KF (Figs. 5A and 5B) experiments calculated more precipitation than experiments using GD (Figs. 5C and 5D). The northern Caribbean side (Belize, Honduras, and northern Nicaragua) is drier than southern Caribbean of Central America (particularly southern Nicaragua and Costa Rica). A similar structure was found in grids 2 and 3 (Fig. S2 and 4, respectively).

Accumulated precipitation over the month was estimated for stations located within the area $9.5^{\circ}-10.5^{\circ} \mathrm{N}-82.5^{\circ}-86^{\circ} \mathrm{W}$, and for their respective, nearest grid-point in each model domain (Fig. 6). Such distribution of the stations was chosen in order to study the rainfall structure, mainly in Costa Rica. Observations and grids detected the same contrast - low (high) rainfall in the West (East) side. Notice that an increase in resolution seemed to improve the precipitation output. In Fig. 6 we are emphasizing a feature that is detected in the observation and in the model, and it is the zonal gradient in precipitation, it is increasing to the East of Costa Rica, particularly during January. Note that the stations selected for

TABLE 3

Monthly total precipitation for January 2000 from gauge stations located in southern Caribbean of Central America (pink dots in Fig. 2a) compared with the nearest grid-point in every domain for different experiments by the product-moment correlation (r), conditional bias (CB), unconditional bias (UCB), skill score (SS), and bias (B)

\begin{tabular}{|c|c|c|c|c|c|c|c|c|}
\hline & \multicolumn{4}{|c|}{ KF2WJ00 } & \multicolumn{4}{|c|}{ KF1WJ00 } \\
\hline & D01 & D02 & D03 & D04 & D01 & D02 & D03 & D04 \\
\hline $\mathrm{r}$ & 0.52 & 0.27 & 0.37 & 0.45 & 0.19 & 0.64 & 0.72 & 0.69 \\
\hline $\mathrm{CB}$ & 0.00 & 0.27 & 0.25 & 0.16 & 0.23 & 0.00 & 0.00 & 0.10 \\
\hline UCB & 0.04 & 0.00 & 0.02 & 0.09 & 0.43 & 0.16 & 0.00 & 0.03 \\
\hline SS & 0.22 & -0.20 & -0.14 & -0.05 & -0.65 & 0.25 & 0.52 & 0.34 \\
\hline \multirow[t]{2}{*}{ Bias } & -42.54 & -6.02 & -31.73 & -60.96 & -135.53 & -81.71 & 1.16 & 36.65 \\
\hline & \multicolumn{4}{|c|}{ GD2WJ00 } & \multicolumn{4}{|c|}{ GD1WJ00 } \\
\hline $\mathrm{r}$ & 0.75 & 0.70 & 0.62 & 0.78 & 0.00 & 0.00 & 0.19 & 0.72 \\
\hline $\mathrm{CB}$ & 0.05 & 0.01 & 0.04 & 0.01 & 0.78 & 0.41 & 0.06 & 0.07 \\
\hline UCB & 0.09 & 0.00 & 0.00 & 0.13 & 1.32 & 2.57 & 2.30 & 0.65 \\
\hline SS & 0.42 & 0.47 & 0.35 & 0.46 & -2.18 & -3.14 & -2.47 & -0.25 \\
\hline Bias & -61.65 & -13.09 & -13.94 & -74.95 & -238.10 & -332.11 & -314.56 & -167.56 \\
\hline
\end{tabular}



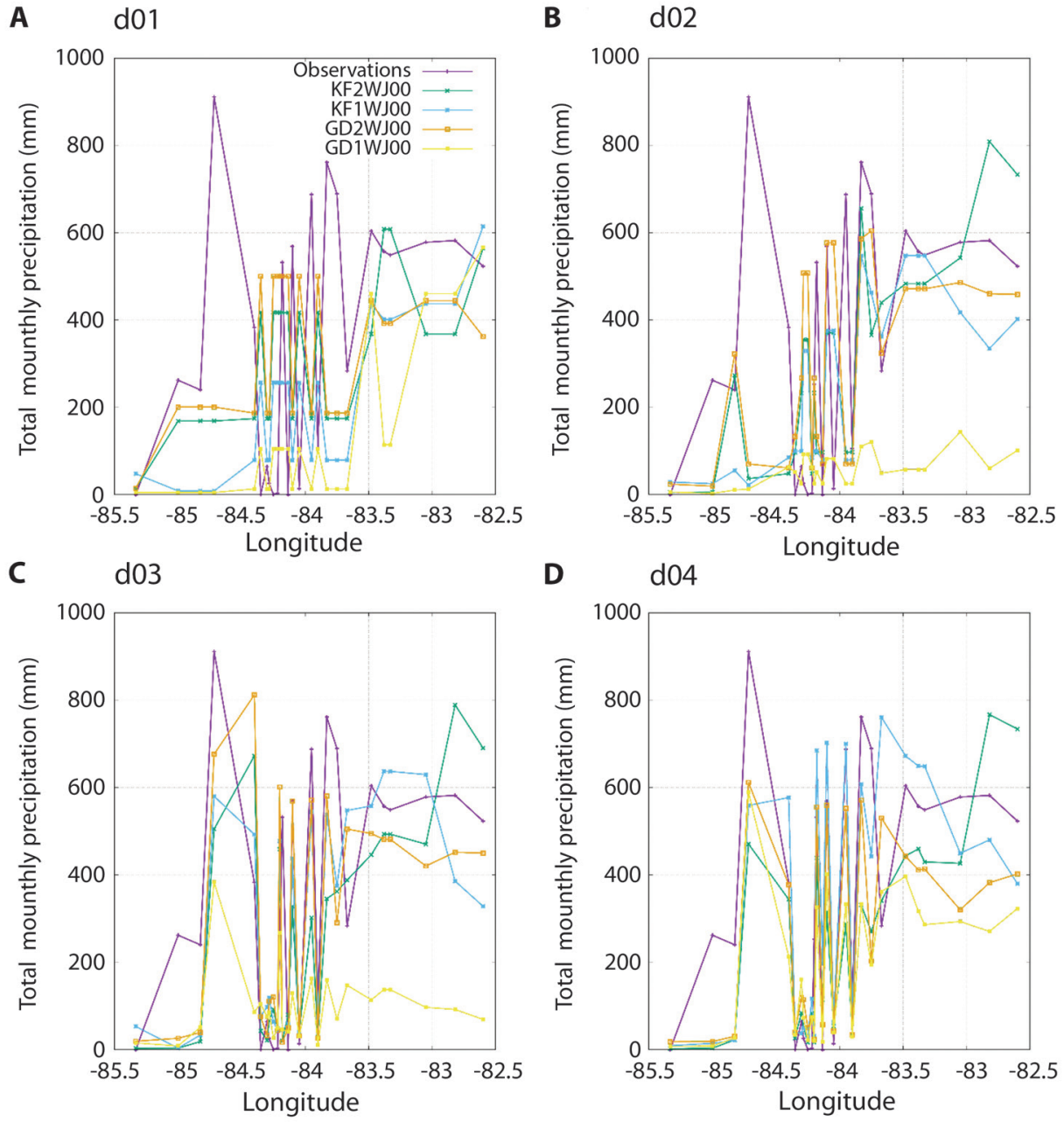

Fig. 6. Monthly accumulated precipitation profiles of the stations and nearest grid-point in each domain, to the gauges within the area $9.5-10.5 \mathrm{~N}-82.5-86 \mathrm{~W}$, for January 2000. The panels show the results from the domains A: d01, B: d02, C: d03 and D: d04.

this comparison are distributed in such a way that there is not more than one station with same longitude.

Table 3 shows the statistical metrics calculated in the southern Caribbean area (Fig. 2A). This region was of special interest, because the observations and model detected heavy rain there. Best correlation and skill score were found in the experiment GD2WJ00 of the domain 4 (Fig. S3C, Table 3). The monthly precipitation was underestimated, about $15 \%$ less than the monthly average $(470 \mathrm{~mm})$ reported by stations in this region during January 2000 . However, the unconditional bias gave evidence that such a value was smaller than the variability observed in the stations. Low value of the conditional bias indicated that the regression is not highly penalized, confirmed by Fig. S3C. A possible explanation is that precipitation is low during January in the Pacific side, in which the dry season is developed during this month.

The configuration KF1WJ00 also showed good results in domain 4 (Fig. S3B), but here, the bias had a clear tendency to overestimate 
the precipitation when comparing the coarse towards the finer domain. Furthermore, precipitation was overestimated about $7 \%$ compared to the monthly average observed in the stations. Conditional and unconditional bias in KF1WJ00 differed from those of the GD2WJ00, and a regression with a positive biased was detected in this case.

The other two cases KF2WJ00 (Fig. S3A) and GD1WJ00 (Fig. S3D) were negatively biased. Notice also that the configuration GD1WJ00 tended to increase rainfall with resolution, but still greatly underestimating precipitation, i.e. about $36 \%$ of the reported amount by the observations. Furthermore, scatter plots of that configuration showed a big dispersion.

South Pacific region (Fig. 2A) exhibited high correlation, and skill scores (Table 4) - mainly in finer domains, nevertheless, the monthly accumulated precipitation was underestimated in the order of $50 \mathrm{~mm}$, in this region (about $35 \%$ of the spatial average during this month).

Simulations for the North Central America (Fig 2A) had the worst performance (Table 5): low correlation, negative skill score, as well as underestimated. However, the interpretation of these results should be done carefully, since the observations and model detected low precipitation in this area.

Time series of the daily rainfall for the stations, and for the grid-points nearest to the stations, located in the south Caribbean region (Fig. 2A) are shown in figure 7. This graph illustrates that the model does represent specific events. At least three precipitation events located between days 1-5, 10-15 and 16-20 were present in all the simulations and in every domain, but these events were not present in the observation. In GD1WJ00 these events were least intense. The model tended to estimate most of the precipitation around days 15-20, while the observed rainfall was located mainly from day 1-20. Time series were also done for stations in north and south Pacific (Fig. 2A), but results did not present any interesting remarkable feature due to low precipitation observed in the model and stations.

September 2007: These experiments showed the same issues at the boundaries related to interaction problems discussed before. In grids $\mathrm{d} 01$ and $\mathrm{d} 02$ (Fig. S4 and S5, respectively), all the experiments revealed an overestimation of rainfall along the ITCZ. Such a surplus was also observed in the inland pattern of rainfall over Central America, being wetter

TABLE 4

Monthly total precipitation for January 2000 from gauge stations located in southern Pacific of Central America (blue dots in Fig. 2a) compared with the nearest grid-point in every domain for different experiments by the product-moment correlation (r), conditional bias (CB), unconditional bias (UCB), skill score (SS), and bias (B)

\begin{tabular}{|c|c|c|c|c|c|c|c|c|}
\hline & \multicolumn{4}{|c|}{ KF2WJ00 } & \multicolumn{4}{|c|}{ KF1WJ00 } \\
\hline & D01 & D02 & D03 & D04 & D01 & D02 & D03 & D04 \\
\hline $\mathrm{r}$ & 0.04 & 0.68 & 0.88 & 0.85 & -0.13 & 0.10 & 0.64 & 0.82 \\
\hline $\mathrm{CB}$ & 0.35 & 0.04 & 0.12 & 0.13 & 0.09 & 0.00 & 0.09 & 0.06 \\
\hline UCB & 0.04 & 0.01 & 0.06 & 0.07 & 0.27 & 0.24 & 0.11 & 0.04 \\
\hline SS & -0.40 & 0.41 & 0.60 & 0.53 & -0.36 & -0.24 & 0.21 & 0.57 \\
\hline \multirow[t]{2}{*}{ Bias } & 45.77 & -26.22 & -52.49 & -56.83 & -113.89 & -106.30 & -73.52 & -44.52 \\
\hline & \multicolumn{4}{|c|}{ GD2WJ00 } & \multicolumn{4}{|c|}{ GD1WJ00 } \\
\hline $\mathrm{r}$ & 0.14 & 0.69 & 0.86 & 0.83 & -0.17 & 0.42 & 0.82 & 0.87 \\
\hline $\mathrm{CB}$ & 0.18 & 0.05 & 0.04 & 0.07 & 0.35 & 0.00 & 0.06 & 0.08 \\
\hline UCB & 0.05 & 0.00 & 0.03 & 0.04 & 0.05 & 0.06 & 0.02 & 0.03 \\
\hline SS & -0.21 & 0.42 & 0.67 & 0.58 & -0.38 & 0.11 & 0.59 & 0.64 \\
\hline Bias & 49.08 & -13.52 & -36.11 & -45.989 & -47.76 & -51.92 & -27.60 & -40.40 \\
\hline
\end{tabular}


TABLE 5

Monthly total precipitation for January 2000 from gauge stations located in northern Central America (green dots in

Fig. 2a) compared with the nearest grid-point in every domain for different experiments by the product-moment correlation (r), conditional bias (CB), unconditional bias (UCB), skill score (SS), and bias (B)

\begin{tabular}{cccccccccc} 
& \multicolumn{9}{c}{ KF2WJ00 } \\
& D01 & D02 & D03 & D04 & D01 & D02 & D03 & D04 \\
r & 0.07 & 0.14 & 0.13 & 0.14 & 0.23 & 0.19 & 0.27 & 0.23 \\
CB & 0.10 & 0.12 & 0.12 & 0.11 & 0.06 & 0.12 & 0.09 & 0.05 \\
UCB & 0.09 & 0.05 & 0.06 & 0.08 & 0.04 & 0.03 & 0.03 & 0.07 & -0.07 \\
SS & -0.19 & -0.15 & -0.16 & -0.17 & -0.05 & -0.12 & -0.05 & -29.40 \\
Bias & -34.38 & -24.42 & -26.65 & -31.61 & -21.88 & -20.35 & -20.53 & \\
& \multicolumn{1}{c}{ GD2WJ00 } & 0.13 & 0.14 & 0.20 & 0.27 & 0.24 & 0.23 & 0.21 \\
r & 0.13 & 0.09 & 0.10 & 0.04 & 0.02 & 0.00 & 0.08 & 0.04 \\
CB & 0.04 & 0.09 & 0.11 & 0.16 & 0.17 & 0.20 & 0.14 & 0.12 \\
UCB & 0.14 & -0.17 & -0.20 & -0.16 & -0.12 & -0.15 & -0.17 & -0.12 \\
SS & -0.16 & -42.14 & -34.49 & -37.77 & -44.91 & -46.43 & -50.32 & -42.68 & -38.53 \\
Bias & -42.14 &
\end{tabular}

A $\quad \mathrm{KF} 2 \mathrm{WJ} 00$

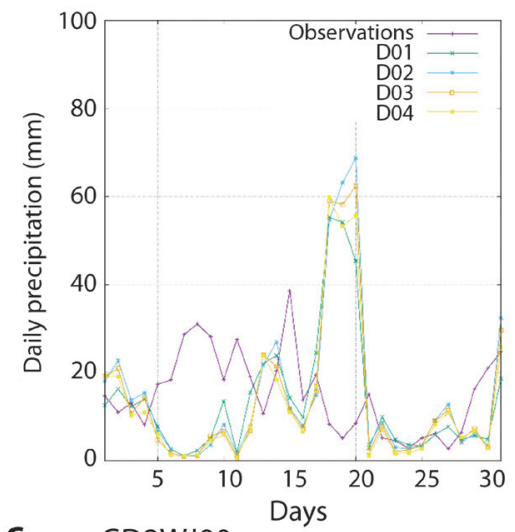

C GD2WJ00

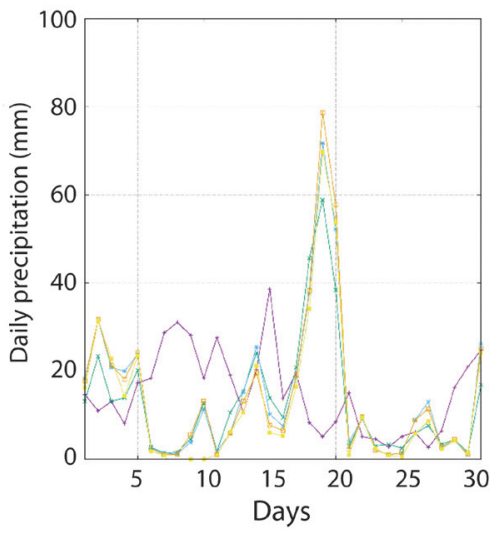

B $\mathrm{KF} 1 \mathrm{WJ} 00$

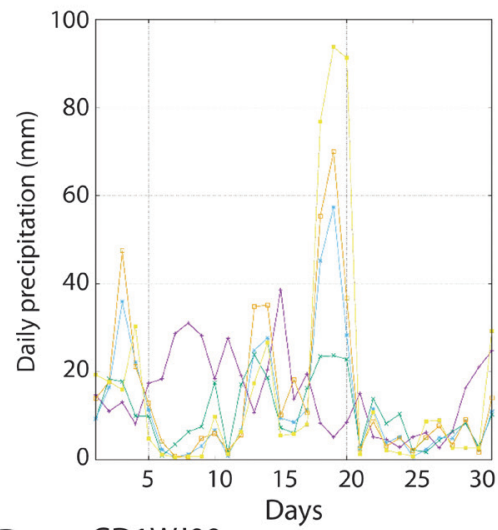

D GD1WJ00

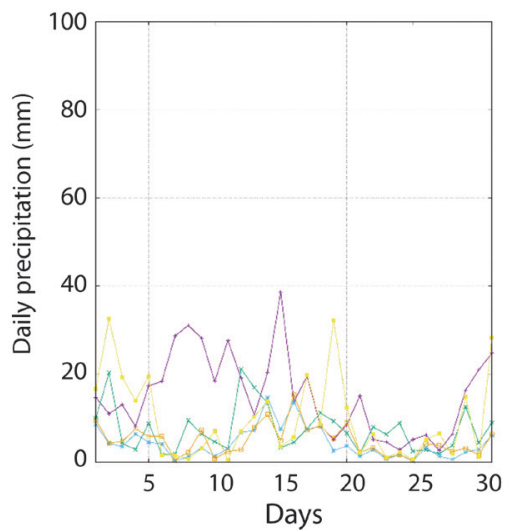

Fig. 7. Daily precipitation time-series of stations and their respective nearest grid-points (with respect to the domain 4) located in the southern Caribbean of Central America (pink dots, Fig. 2A) for different domains during January 2000 in A: KF2WJ00, B: KF1WJ00, C: GD2WJ00 and D: GD1WJ00. 
at the Pacific coast during September than in January, as was expected. Furthermore, the ITCZ seemed to be located further north compared to the experiments for January, which indicated that the model was capturing the annual migration of the ITCZ (also observed in NCEP-NCAR reanalysis, Fig. 3). Both KF2WS07 and KF1WS07 cases showed the same instabilities close to the Andes found for January. Moreover, all the cases also showed the area of heavy rainfall near the Pacific coast of Colombia, but larger in extent and intensity than during January, in agreement with the annual cycle of average precipitation showed in Poveda \& Mesa (2000). Particularly, KF2WS07 (GD1WS07) estimated the highest (lowest) amount of precipitation in this area.
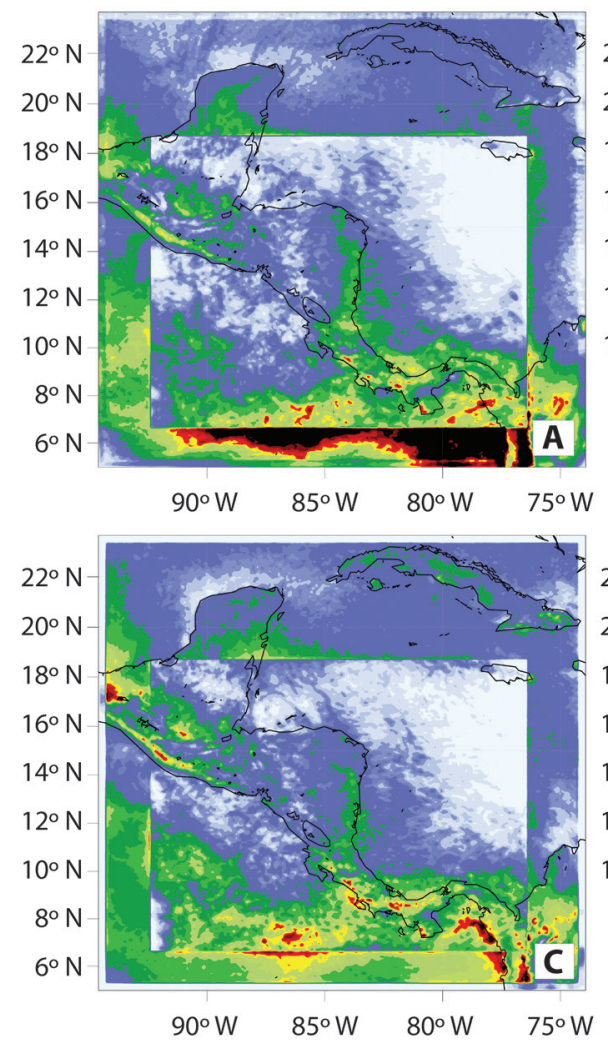

The KF1WS07 and GD1WS07 experiments for domain 3 (Fig. 8), showed a particular maximum along the Caribbean coast of Nicaragua that was not found in their corresponding experiments using two-way nesting (KF2WS07 and GD2WS07). Also, KF1WS07 and GD1WS07 produced more precipitation along the Pacific coast of Costa Rica, and Panama, indicating possible intrusions of the ITCZ.

Significant differences in the spatial distribution and amount of precipitation were found in the experiments the coarser grids d01, d02 and $\mathrm{d} 03$ (Figs. S4, S5 and 8). Nonetheless, these discrepancies were not reflected in their corresponding finer domain (Fig. 9), where all the tests showed a similar pattern of rainfall on Central America. However, one could say that
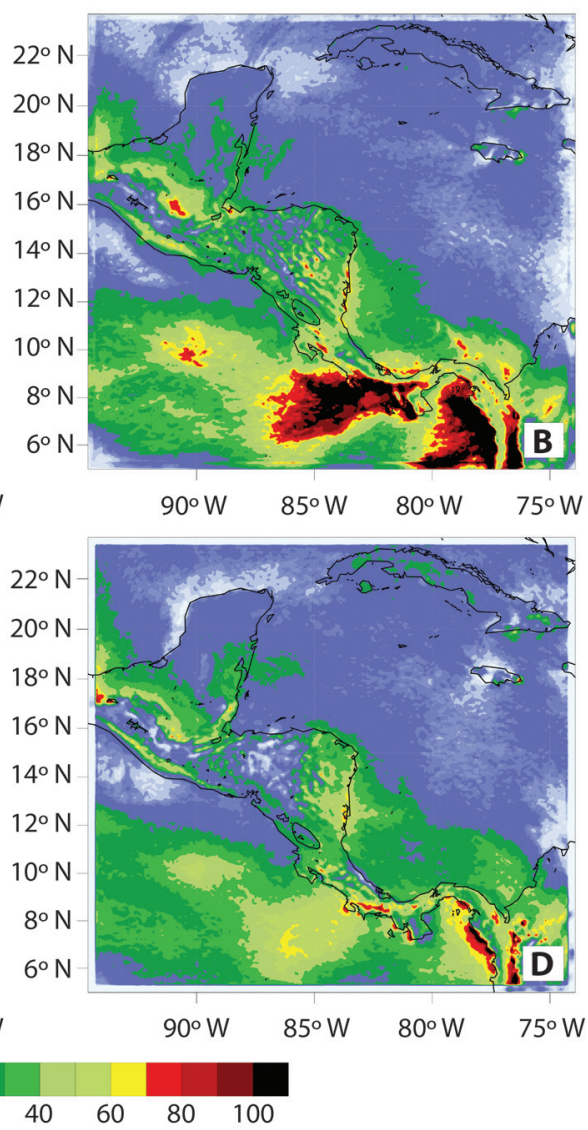

Fig. 8. Average daily precipitation rates for domain $3(10 \mathrm{~km})$ for September 2007 using different experiments: scheme Kain-Fritsch (KF) in $\mathbf{A}$ and $\mathbf{B}$, scheme Grell-Devenyi (GD) in $\mathbf{C}$ and $\mathbf{D}$ and using two-way nesting $\mathbf{A}$ and $\mathbf{C}$ and one-way nesting $\mathbf{B}$ and $\mathbf{D}$ for each scheme. See text for explanation of discontinuities in Fig. 4 A, C. 
those runs allowing one-way nesting tended to produce more precipitation, mainly, along the south boundary, where all seemed to capture part of the ITCZ, is detected as the relative maxima of precipitation in the southern edge of the domain. GD2WS07 and GD1WS07 cases showed some intrusions of the ITCZ over southern Pacific coast of Costa Rica. Notice also that these experiments show this fringe a little bit north up. Also, note that the experiments detected a relative maximum right over the western Caribbean coast of Panama. In experiments GD this maximum was weaker compared to the KF.

Similar precipitation profiles as for the month of January 2000 were done for September 2007 (Fig. 10). A larger precipitation spot was located over the Pacific than on the Caribbean side, opposite to January rainfall pattern (Fig. 10). Experiments KF1WS07 and GD1WS07 showed a better representation of this pattern in grids 3 , but not so in domain 4. Other cases did not reproduce this structure. KF2WS07 had the worst results. A KS test (Table 6) indicated that in KF1WS07, GD2WS07, and GD1WS07, domain 3, the null hypothesis was accepted at the $95 \%$ of confidence. In agreement with previous results in this study the Kain-Fritsch scheme produced more prediction than the Grell-Devenyi scheme, a feature also found in Mapes, Warner, $\mathrm{Xu}, \&$ Gochis (2004). The latter has been associated with the ability of the GD scheme to reproduce spotty but intense rainfall, and apparently was reluctant to activate, frequently yielding little or no rain. However, when rainfall did develop, it was very intense.

Metrics were calculated for the same three areas (Fig. 2B), also studied for the January case (Tables 3 to 5): south Caribbean, south Pacific, and north Central America (Tables 7,8 and 9 , respectively). Best results were
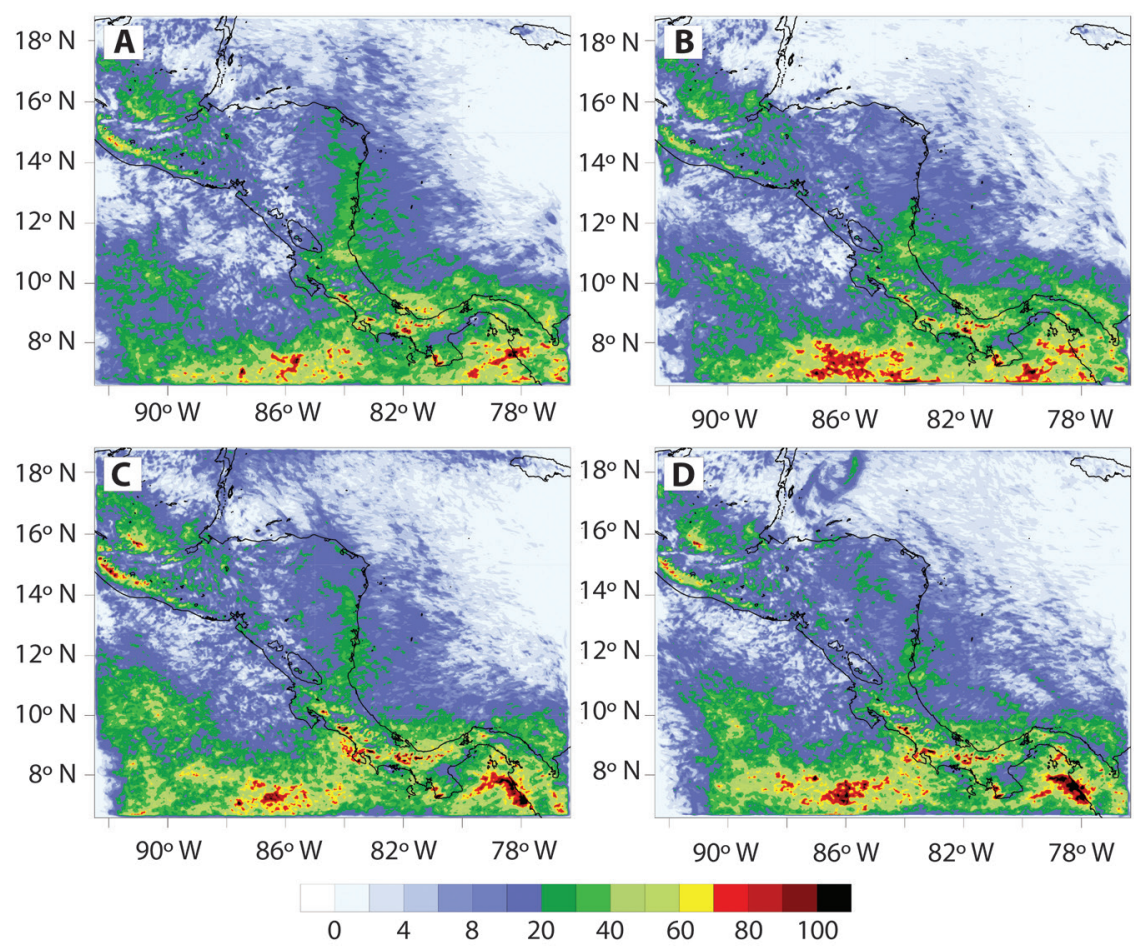

Fig. 9. Average daily precipitation rates for domain $4(3.3 \mathrm{~km})$ for September $2007 \mathrm{using}$ different experiments: scheme Kain-Fritsch (KF) in $\mathbf{A}$ and $\mathbf{B}$, scheme Grell-Devenyi (GD) in $\mathbf{C}$ and $\mathbf{D}$ and using two-way nesting $\mathbf{A}$ and $\mathbf{C}$ and one-way nesting $\mathbf{B}$ and $\mathbf{D}$ for each scheme. 

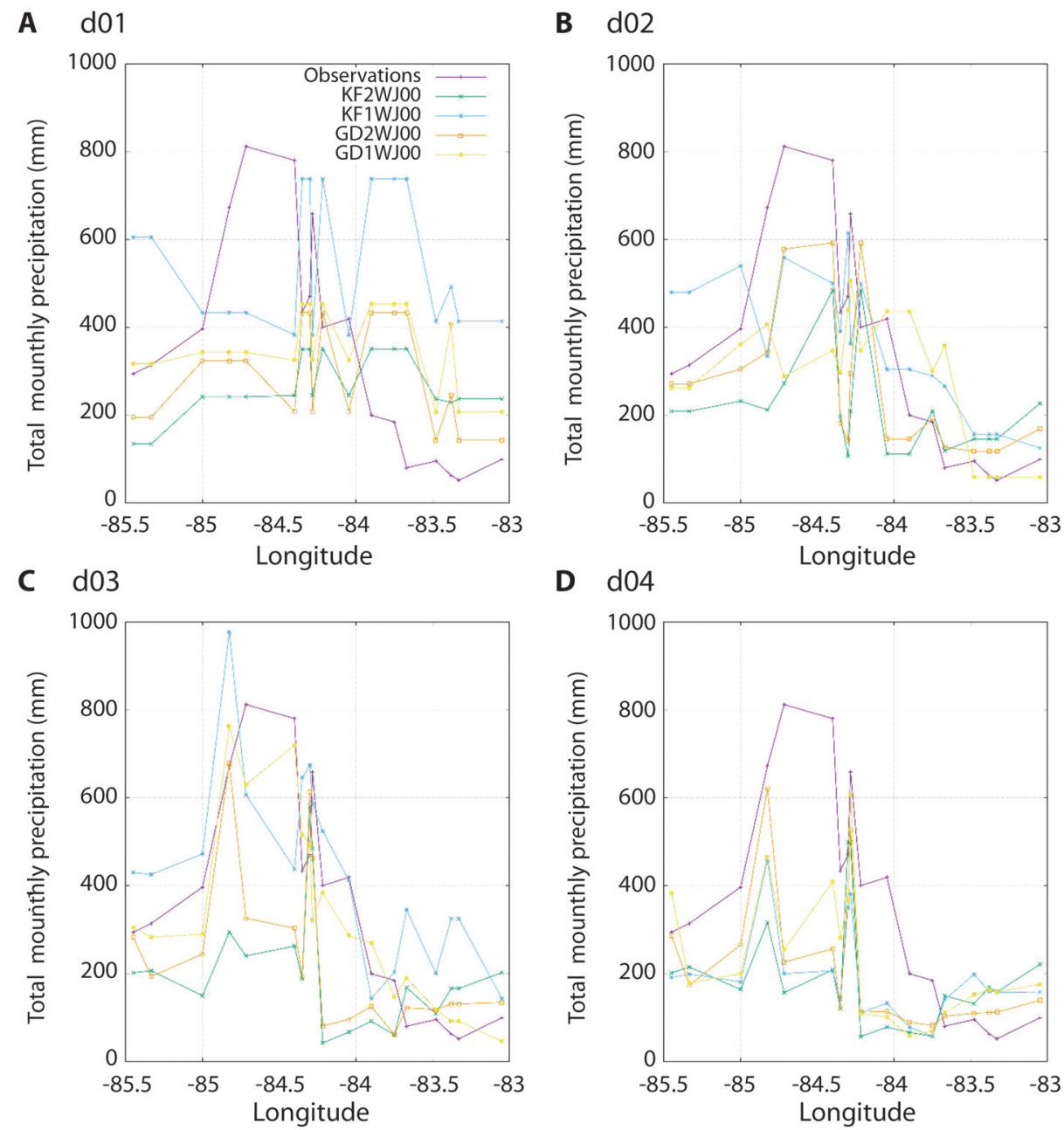

Fig. 10. Monthly accumulated precipitation profiles of the stations and nearest grid-point in each domain, to the gauges within the area $9.5-10.5 \mathrm{~N}-82.5-86 \mathrm{~W}$, for September 2007. The panels show the results from the domains A: d01, B: d02, C: d03 and D: d04.

TABLE 6

Two-sided Kolmogorov-Smirnov test between observations and model outputs of September 2007 monthly total precipitation profiles in Fig. 14. Numbers in bold are within the $95 \%$ of confidence level. In parenthesis are the p-values

\begin{tabular}{ccccc} 
Domain/Experiment & KF2WJ00 & KF1WJ00 & GD2WJ00 & GD1WJ00 \\
D01 & $0.50(0.01)$ & $0.50(0.01)$ & $\mathbf{0 . 3 3 ( 0 . 2 2 )}$ & $\mathbf{0 . 3 9 ( 0 . 1 0 )}$ \\
D02 & $0.50(0.01)$ & $\mathbf{0 . 2 8 ( 0 . 4 3 )}$ & $\mathbf{0 . 3 3 ( 0 . 2 2 )}$ & $\mathbf{0 . 2 2 ( 0 . 7 1 )}$ \\
D03 & $0.44(0.04)$ & $\mathbf{0 . 2 8}(\mathbf{0 . 4 3})$ & $\mathbf{0 . 3 3 ( 0 . 2 2 )}$ & $\mathbf{0 . 2 2}(\mathbf{0 . 7 1})$ \\
D04 & $0.44(0.04)$ & $0.44(0.04)$ & $0.44(0.04)$ & $\mathbf{0 . 3 3 ( 0 . 2 2 )}$ \\
\hline
\end{tabular}


TABLE 7

September 2007 monthly total precipitation from gauge stations located in southern Caribbean of Central America (pink dots in Fig. 2a) are compared with the nearest grid-point in every domain from the experiments. The metrics shown here are the product-moment correlation (r), conditional bias (CB), unconditional bias (UCB), skill score (SS), and bias (B)

\begin{tabular}{cccccccccc} 
& \multicolumn{9}{c}{ KF2WJ00 } \\
& D01 & D02 & D03 & D04 & D01 & D02 & D03 & D04 \\
r & 0.19 & 0.26 & 0.42 & 0.32 & -0.05 & 0.46 & 0.48 & 0.31 \\
CB & 0.09 & 0.06 & 0.04 & 0.04 & 0.28 & 0.28 & 0.04 & 0.02 \\
UCB & 0.12 & 0.01 & 0.04 & 0.01 & 0.99 & 0.12 & 0.30 & 0.00 \\
SS & -0.18 & -0.01 & 0.09 & 0.06 & -1.39 & -0.21 & -0.15 & 0.07 \\
Bias & 79.54 & 27.32 & 45.12 & 22.73 & 231.15 & 81.97 & 128.42 & 11.73 \\
& \multicolumn{1}{c}{ GD2WJ00 } & & & GD1WJ00 & \\
r & 0.24 & 0.25 & 0.50 & 0.48 & 0.22 & 0.42 & 0.90 & 0.85 \\
CB & 0.07 & 0.10 & 0.05 & 0.04 & 0.16 & 0.31 & 0.01 & 0.13 \\
UCB & 0.00 & 0.00 & 0.01 & 0.00 & 0.20 & 0.00 & 0.01 & 0.00 \\
SS & -0.01 & -0.04 & 0.18 & 0.18 & -0.34 & -0.13 & 0.79 & 0.59 \\
Bias & 14.41 & -3.84 & 27.32 & 11.02 & 103.51 & -10.39 & 21.62 & 16.08 \\
\hline
\end{tabular}

TABLE 8

September 2007 monthly total precipitation from gauge stations located in southern Pacific region of Central America (blue dots in Fig. 2a) are compared with the nearest grid-point in every domain from the experiments. The metrics shown here are the product-moment correlation (r), conditional bias (CB), unconditional bias (UCB), skill score (SS), and bias (B)

\begin{tabular}{|c|c|c|c|c|c|c|c|c|}
\hline & \multicolumn{4}{|c|}{ KF2WJ00 } & \multicolumn{4}{|c|}{ KF1WJ00 } \\
\hline & D01 & D02 & D03 & D04 & D01 & D02 & D03 & D04 \\
\hline $\mathrm{r}$ & -0.20 & -0.05 & 0.01 & -0.01 & 0.04 & 0.26 & 0.16 & 0.08 \\
\hline $\mathrm{CB}$ & 0.13 & 0.10 & 0.10 & 0.11 & 0.06 & 0.00 & 0.03 & 0.02 \\
\hline UCB & 0.21 & 0.22 & 0.21 & 0.23 & 0.00 & 0.04 & 0.00 & 0.26 \\
\hline SS & -0.31 & -0.33 & -0.32 & -0.35 & -0.06 & 0.02 & -0.01 & -0.28 \\
\hline \multirow[t]{2}{*}{ Bias } & -285.36 & -291.10 & -284.17 & -297.33 & 34.07 & -126.81 & 31.90 & -314.95 \\
\hline & \multicolumn{4}{|c|}{ GD2WJ00 } & \multicolumn{4}{|c|}{ GD1WJ00 } \\
\hline $\mathrm{r}$ & -0.16 & 0.05 & 0.01 & 0.00 & -0.08 & -0.11 & 0.28 & 0.02 \\
\hline $\mathrm{CB}$ & 0.13 & 0.07 & 0.10 & 0.09 & 0.05 & 0.06 & 0.00 & 0.09 \\
\hline UCB & 0.13 & 0.13 & 0.16 & 0.19 & 0.07 & 0.12 & 0.06 & 0.17 \\
\hline SS & -0.24 & -0.20 & -0.26 & -0.28 & -0.12 & -0.17 & 0.02 & -0.28 \\
\hline Bias & -223.53 & -222.97 & -248.01 & -269.08 & -166.62 & -211.86 & -148.89 & -260.09 \\
\hline
\end{tabular}

found for the south Caribbean area, where 227 $\mathrm{mm}$ average monthly rainfall was reported by the stations. In GD configurations, the inner domain had the highest correlation and skill score. In both cases about $5 \%$ of the monthly accumulated precipitation reported by stations, was overestimated, contrary with their respective cases for January. From figure S6 and Table 7, one can see that GD1WS07 had the best fit in a linear regression and skill score.
In both the south Pacific and north Central America results exhibited negative and low correlations and skill score (Tables 8 and 9). This suggested that the model was not doing a good performance calculating rainfall over those regions, particularly in the south Pacific area, which in turn, also presented the highest amount of the average monthly accumulated precipitation $(535 \mathrm{~mm})$.

The daily precipitation time-series of the model were featureless for the month of 
TABLE 9

September 2007 monthly total precipitation from gauge stations located in northern Pacific Central America (green dots in Fig. 2a) are compared with the nearest grid-point in every domain from the experiments. The metrics shown here are the product-moment correlation (r), conditional bias (CB), unconditional bias (UCB), skill score (SS), and bias (B)

\begin{tabular}{|c|c|c|c|c|c|c|c|c|}
\hline & \multicolumn{4}{|c|}{ KF2WJ00 } & \multicolumn{4}{|c|}{ KF1WJ00 } \\
\hline & D01 & D02 & D03 & D04 & D01 & D02 & D03 & D04 \\
\hline $\mathrm{r}$ & 0.10 & 0.03 & 0.00 & 0.05 & 0.47 & 0.23 & 0.72 & -0.01 \\
\hline $\mathrm{CB}$ & 0.13 & 0.60 & 0.93 & 0.80 & 0.12 & 0.64 & 1.85 & 0.70 \\
\hline UCB & 0.01 & 0.07 & 0.02 & 0.02 & 0.99 & 1.70 & 3.54 & 0.00 \\
\hline SS & -0.13 & -0.66 & -0.95 & -0.82 & -0.95 & -2.39 & -5.05 & -0.70 \\
\hline \multirow[t]{2}{*}{ Bias } & 10.23 & 33.13 & 18.21 & 18.09 & 128.66 & 168.49 & 243.19 & -0.75 \\
\hline & \multicolumn{4}{|c|}{ GD2WJ00 } & \multicolumn{4}{|c|}{ GD1WJ00 } \\
\hline $\mathrm{r}$ & -0.04 & -0.13 & -0.16 & -0.12 & 0.58 & 0.09 & 0.47 & -0.23 \\
\hline $\mathrm{CB}$ & 0.37 & 1.44 & 1.58 & 1.43 & 0.07 & 0.56 & 0.31 & 1.76 \\
\hline $\mathrm{UCB}$ & 0.05 & 0.29 & 0.12 & 0.11 & 0.13 & 0.27 & 0.35 & 0.06 \\
\hline SS & -0.42 & -1.73 & -1.68 & -1.54 & 0.12 & -0.84 & -0.47 & -1.77 \\
\hline Bias & 28.05 & 69.59 & 43.92 & 42.61 & 46.92 & 67.07 & 76.88 & 31.41 \\
\hline
\end{tabular}

September 2007 (not shown). No agreement between the observation and prediction was found. So, it gave evidence that using the chosen configuration the model did not reproduce specific events in both cases January 2000 and September 2007.

\section{SUMMARY AND CONCLUSIONS}

In January 2000 results showed that the model was detecting mean climate features in magnitude, and spatial distribution, for both, at the mesoscale resolution grids, $\mathrm{d} 01$ and $\mathrm{d} 02$, or at finer resolution grids, d03 and d04. It is important to notice the contrast in the precipitation structure over southern Central America observed by the stations and in the model outputs, having a maximum upon south Caribbean region. This was in agreement with the climatology during this season reported in Alfaro (2002), Taylor \& Alfaro (2005), and Amador et al. (2006). In addition, this result reflected the ability of the model to solve the interaction between the topography and the northeasterly flow during January in this region.

The poor performance during September 2007 experiments could be related to some issues found in the boundary conditions (NCEP/NCAR data), such as those found here.
GCM has difficulty in reproducing transitions from warm to cold ENSO episodes (Janowiak, Gruber, Kondragunta, Livezey, \& Huffman, 1998). A list with the main results from these experiments is shown:

For the month of January, the results showed that the WRF model had some ability in reproducing the main precipitation structures (in spatial distribution and magnitude); this can be noticed by comparing with the observed data, and because the results were in agreement with the climatology during January 2000.

Results from September 2007 experiments disagreed substantially with the observations and with the climatology. Despite that, results suggested that dynamical downscaling techniques could be used to study the climatology of regional and local scale circulations as the IALLJ or the Chocó jet, which are very important elements in producing rainfall in Central America. Results showed that this model is also capable to capture the interaction between sharp topography and the easterly wind flow.

The integration period, including the spinup time ( 5 days plus $6 \mathrm{~h}$ ), used for simulations in this study, was not adequate to represent specific events, but did a good estimation of the average daily precipitation rates. However, it should be noticed that during for both, 
January or September, and for the meso- and small-scale events such as cold surges during the first month, or the "temporales" in the second case, were a very important mechanism in producing rainfall in the isthmus (Amador et al., 2006). The latter is opening the doors to explore other integration periods, possibly shorter than the one used here, in order to study such kind of events.

Discontinuities in precipitation fields were found in experiments using two-ways nesting of the domains 1, 2 and 3, all of which used a hybrid convection scheme (explicit and implicit). Such discontinuities coincided with the same area where the inner domain was defined, and where the only explicit convection scheme was used. Such irregular patterns were not observed in other variables like temperature, wind or humidity field (not shown here). Similar irregular patterns were reported firstly by Warner \& Hsu (2000) using MM5 model, and, then, by Bukovsky \& Karoly (2009) using WRF model.

Our results here provided evidence that there are still problems with the current cumulus schemes in mesoscale models, which are not model dependent. Such issues, nevertheless, have been related to the adjustment of the mass field between the inner and outer domains (Warner \& Hsu, 2000), also with the formulation of the cumulus convection problem itself (Arakawa, 2004).

\section{ACKNOLEDGEMENTS}

This research was carried out within the CNDS research school, supported by the Swedish International Development Cooperation Agency (SIDA) through their contract with the International Science Programme (ISP) at Uppsala University (contract number: 54100006). This work was supported by the following UCR grants: 805-B7-507, B6-143 (both supported also by CONICIT-MICITT), B4-227, B0-065, A9-532 (supported also by CSUCA-ASDI), 850-B7-286, 805-B7-286 (supported by UCREA) and B0-810.

\section{RESUMEN}

Estimaciones de precipitación regional en América Central usando el model Weather Research and Forecast: Utilizando el modelo climático regional WRF y los datos del Proyecto de Reanálisis del NCEP-NCAR como condiciones iniciales y de frontera, se estimó la precipitación regional para Centroamérica mediante la técnica de reducción dinámica para dos períodos seleccionados, enero de 2000 y septiembre de 2007. Cuatro dominios anidados se configuraron en esta región, d01, d02, d03 y d04 con resoluciones de $90 \mathrm{~km}, 30 \mathrm{~km}, 10 \mathrm{~km}$ y $3.3 \mathrm{~km}$ respectivamente. Las simulaciones se reinicializaron cada 5 días con 6 horas de tiempo de ajuste del modelo. Un total de 8 experimentos (4 por mes) fueron probados con el fin de estudiar: a) dos importantes Esquemas de Parametrización de Cumulus: Kain-Fritsch (KF) y Grell-Devenyi (GD); y b) la interacción física entre dominios anidados (respuesta de un y doble sentido), durante cada mes simulado. En enero de 2000 los resultados mostraron que la precipitación modelada está de acuerdo con las observaciones y también capturó las características climáticas de la precipitación respecto a la magnitud y la distribución espacial, como el contraste de precipitación particular entre la costa del Pacífico y el Caribe. Los resultados de septiembre de 2007 revelaron diferencias significativas cuando se hace una comparación visual con la distribución espacial de cada dominio grueso (d01, d02 y d03) con su dominio respectivo en cada experimento. Sin embargo, los dominios d04 de todos los experimentos mostraron una distribución espacial y una estimación de magnitud similares, principalmente en aquellas series que usan una configuración de anidamiento unidireccional. Por otra parte, los resultados de este mes difieren sustancialmente con las observaciones, y este último podría estar relacionado con deficiencias asociadas en la condición de frontera que no reproducen bien los períodos de transición de los episodios de cálido a frío del ENOS. Además, en todos los experimentos, el esquema KF calculó más precipitación que el esquema GD y está asociado a la capacidad del esquema GD para reproducir lluvias irregulares pero intensas, y aparentemente este esquema es reacio a activarse, produciendo lluvia con poca frecuencia o ninguna. Sin embargo, cuando la lluvia se desarrolla, es muy intensa. Además, las series de tiempo no replican eventos de precipitación específicos, por lo tanto, el período de integración de 5 días usado en este estudio, no es suficiente para reproducir eventos de precipitación a corto plazo. Por último, los problemas de interacción física entre los dominios anidados se reflejan en las discontinuidades en el campo de precipitación, que se han asociado con el ajuste del campo de masa en el CPS.

Palabras clave: reducción de escala dinámica, modelos regionales, reanálisis, esquemas de parametrización de cumulus, América Central. 


\section{REFERENCES}

Alfaro, E. J. (2000). Eventos cálidos y fríos en el Atlántico Tropical Norte. Atmósfera, 13(2), 109119. Retrieved from http://www.kerwa.ucr.ac.cr/ handle/10669/15224

Alfaro, E. J. (2002). Some Characteristics of the Annual Precipitation Cycle in Central America and their Relationships with its Surrounding Tropical Oceans. Tópicos Meteorológicos y Oceanográficos, 9, 1-13.

Alfaro, E. J. (2007). Uso del análisis de correlación canónica para la predicción de la precipitación pluvial en Centroamérica. Ingeniería y Competitividad, 9(2), 33-48. Retrieved from http://bibliotecadigital.univalle.edu.co/xmlui/handle/10893/1622

Alfaro, E. J., Quesada, A., Solano-Chaves, F. J., AlfaroMartínez, E. J., Quesada-Román, A., \& SolanoChaves, F. J. (2010). Análisis del Impacto en Costa Rica de los Ciclones Tropicales Ocurridos en el Mar Caribe desde 1968 al 2007. Diálogos Revista Electrónica, 11(2), 22-38. Retrieved from http://revistas.ucr. ac.cr/index.php/dialogos/article/view/578

Amador, J. A. (2008). The Intra-Americas Sea Low-level Jet Overview and Future Research. Annals of the New York Academy of Sciences, 1146(1), 153-188. https:// doi.org/10.1196/annals.1446.012

Amador, J. A., \& Alfaro, E. J. (2009). Métodos de reducción de escala: aplicaciones al tiempo, clima, variabilidad climática y cambio climático. Revista Iberoamericana de Economía Ecológica, 11, 39-52. Retrieved from http://dialnet.unirioja.es/servlet/ articulo? codigo $=3190247$

Amador, J. A., Alfaro, E. J., Lizano, O. G., \& Magaña, V. O. (2006). Atmospheric forcing of the eastern tropical Pacific: A review. Progress in Oceanography, 69(2-4), 101-142. https://doi.org/10.1016/j. pocean.2006.03.007

Amador, J. A., Rivera, E. R., Durán-Quesada, A. M., Mora, G., Sáenz, F., Calderón, B., \& Mora, N. (2016). The easternmost tropical Pacific. Part I: A climate review. Revista de Biología Tropical, 64(1), S1-S22. https:// doi.org/10.15517/rbt.v64i1.23407

Arakawa, A. (2004). The Cumulus Parameterization Problem: Past, Present, and Future. Journal of Climate, 17(13), 2493-2525. https://doi. org/10.1175/1520-0442(2004)017<2493:RATCPP $>2$ $.0 . \mathrm{CO} ; 2$

Bukovsky, M. S., \& Karoly, D. J. (2009). Precipitation Simulations Using WRF as a Nested Regional Climate Model. Journal of Applied Meteorology and Climatology, 48(10), 2152-2159. https:// doi.org/10.1175/2009JAMC2186.1

Dudhia, J. (1989). Numerical Study of Convection Observed during the Winter Monsoon Experiment
Using a Mesoscale Two-Dimensional Model. Journal of the Atmospheric Sciences. https://doi. org/10.1175/1520-0469(1989)046<3077:NSOCOD> 2.0.CO;2

Dudhia, J., Hong, S. Y., \& Lim, K. S. (2008). A New Method for Representing Mixed-phase Particle Fall Speeds in Bulk Microphysics Parameterizations. Journal of the Meteorological Society of Japan. Ser. $I I, 86 A, 33-44$. Retrieved from https://www.jstage.jst. go.jp/article/jmsj/86A/0/86A_0_33/_pdf

Enfield, D.B. (1996). Relationships of inter-American rainfall to tropical Atlantic and Pacific SST variability. Geophys. Res. Lett., 23, 3505-3508.

Enfield, D. B., \& Alfaro, E. J. (1999). The Dependence of Caribbean Rainfall on the Interaction of the Tropical Atlantic and Pacific Oceans. Journal of Climate, 12(7), 2093-2103. https://doi. org/10.1175/1520-0442(1999)012<2093:TDOCRO > 2.0.CO;2

Enfield, D. B., Lee, S. K., \& Wang, C. (2006). How are large western hemisphere warm pools formed? Progress in Oceanography, 70(2), 346-365. https://doi. org/10.1016/j.pocean.2005.07.006

Fiedler, P. C., \& Lavín, M. F. (2006). Introduction: A review of eastern tropical Pacific oceanography. Progress in Oceanography, 69(2-4), 94-100. https://doi. org/10.1016/j.pocean.2006.03.006

Giannini, A., Kushnir, Y., \& Cane, M. A. (2000). Interannual Variability of Caribbean Rainfall, ENSO, and the Atlantic Ocean. J. Climate, 13, 297-311, https:// doi.org/10.1175/1520-0442(2000)013<0297:IVOCR $\mathrm{E}>2.0 . \mathrm{CO} ; 2$

Gochis, D. J., Shuttleworth, W. J., \& Yang, Z. L. (2002). Sensitivity of the Modeled North American Monsoon Regional Climate to Convective Parameterization. Monthly Weather Review, 130(5), 1282-1298. https:// doi.org/10.1175/1520-0493(2002)130<1282:SOTM $\mathrm{NA}>2.0 . \mathrm{CO} ; 2$

Grell, G. A., \& Dévényi, D. (2002). A generalized approach to parameterizing convection combining ensemble and data assimilation techniques. Geophysical Research Letters, 29(14), 38-1-38-4. https://doi. org/10.1029/2002GL015311

Hastenrath, S. (1967). Rainfall distribution and regime in Central America. Arch. Meteor. Geophys. Biokl. Ser $B, 15,201-241$.

Hernandez, J. L., Srikishen, J., Erickson III, D. J., Oglesby, R., Irwin, D., Erickson, D. J., ... Irwin, D. (2006). A regional climate study of Central America using the MM5 modeling system: results and comparison to observations. International Journal of Climatology, 26(15), 2161-2179. https://doi.org/10.1002/joc.1361 
Hidalgo, H. G., Durán-Quesada, A. M., Amador, J. A., \& Alfaro, E. J. (2015). The Caribbean Low-Level Jet, the Inter-Tropical Convergence Zone and Precipitation Patterns in the Intra-Americas Sea: A Proposed Dynamical Mechanism. Geografiska Annaler: Series A, Physical Geography, 97(1), 41-59. https://doi. org/10.1111/geoa.12085

Hong, S. Y., \& Pan, H. L. (1996). Nonlocal Boundary Layer Vertical Diffusion in a Medium-Range Forecast Model. Monthly Weather Review, 124(10), 2322-2339. https:// doi.org/10.1175/1520-0493(1996)124<2322:NBLVD $\mathrm{I}>2.0 . \mathrm{CO} ; 2$

Instituto Meteorológico Nacional. (2004). Boletín Meteorológico Mensual - Enero 2000. San José, Costa Rica: Instituto Meteorológico Nacional.

Instituto Meteorológico Nacional. (2007). Boletín Meteorológico Mensual - Septiembre 2007. San José, Costa Rica: Instituto Meteorológico Nacional.

Janowiak, J. E., Gruber, A., Kondragunta, C. R., Livezey, R. E., \& Huffman, G. J. (1998). A Comparison of the NCEP-NCAR Reanalysis Precipitation and the GPCP Rain Gauge-Satellite Combined Dataset with Observational Error Considerations. Journal of Climate, 11(11), 2960-2979. https://doi. org/10.1175/1520-0442(1998)011<2960:ACOTNN> 2.0. $\mathrm{CO} ; 2$

Kain, J. S., \& Fritsch, J. M. (1990). A One-Dimensional Entraining/Detraining Plume Model and Its Application in Convective Parameterization. J. Atmos. Sci., 47, 2784-2802.

Kain, J. S., \& Fritsch, J. M. (1992) The role of the convective "trigger function" in numerical forecasts of mesoscale convective systems. Meteor. Atmos. Phys., 49, 93-106.

Kain, J. S. (2004). The Kain-Fritsch Convective Parameterization: An Update. Journal of Applied Meteorology, 43(1), 170-181. https://doi. org/10.1175/1520-0450(2004)043<0170:TKCPAU> 2.0. $\mathrm{CO} ; 2$

Kalnay, E., Kanamitsu, M., Kistler, R., Collins, W., Deaven, D., Gandin, L., ... Joseph, D. (1996). The NCEP/ NCAR 40-year reanalysis project. Bulletin of the American Meteorological Society, 77(3), 437-471.

Kistler, R., Collins, W., Saha, S., White, G., Woollen, J., Kalnay, E., ... Fiorino, M. (2001). The NCEPNCAR 50-Year Reanalysis: Monthly Means CDROM and Documentation. Bulletin of the American Meteorological Society, 82(2), 247-267. https://doi. org/10.1175/1520-0477(2001)082<0247:TNNYRM> 2.3. $\mathrm{CO} ; 2$

Lawrimore, J. H., Menne, M. J., Gleason, K. L., Easterling, D. R., Heim, R. R., Halpert, M. S., ... Alexander, L. (2001). Climate Assessment for 2000. Bulletin of the American Meteorological Society,
82(6), 1304-1304. https://doi.org/10.1175/15200477(2001)082<1304:CAF>2.3.CO;2

Lee, S. K., Enfield, D. B., \& Wang, C. (2007). What Drives the Seasonal Onset and Decay of the Western Hemisphere Warm Pool? Journal of Climate, 20(10), 21332146. https://doi.org/10.1175/JCLI4113.1

Levinson, D. H., \& Lawrimore, J. H. (2008). State of the Climate in 2007. Bulletin of the American Meteorological Society, 89(7), S1-S179. https://doi. org/10.1175/BAMS-89-7-StateoftheClimate

Louis, J. F., (1979). A parametric model of vertical eddy fluxes in the atmosphere. Bound.-Layer Meteor., 17, 187-202.

Magaña, V., Amador, J. A., \& Medina, S. (1999). The midsummer drought over Mexico and Central America. Journal of Climate, 12(6), 1577-1588. https://doi. org/10.1175/1520-0442(1999)012<1577:TMDOMA $>2.0 . \mathrm{CO} ; 2$

Maldonado, T., \& Alfaro, E. J. (2010). Propuesta metodológica para la predicción climática estacional de eventos extremos y días con precipitación. Estudio de caso: Sur de América Central. InterSedes, 11(21), 182-214. Retrieved from http://www.intersedes.ucr. ac.cr/ojs/index.php/intersedes/article/view/269

Maldonado, T., \& Alfaro, E. J. (2011). Predicción estacional para ASO de eventos extremos y días con precipitación sobre las vertientes Pacífico y Caribe de América Central, utilizando análisis de correlación canónica. InterSedes, 12(24), 78-108. Retrieved from http://www.intersedes.ucr.ac.cr/ojs/index.php/ intersedes/article/view/301

Maldonado, T., Alfaro, E. J., Fallas-López, B., \& Alvarado, L. (2013). Seasonal prediction of extreme precipitation events and frequency of rainy days over Costa Rica, Central America, using Canonical Correlation Analysis. Advances in Geosciences, 33, 41-52. https://doi.org/10.5194/adgeo-33-41-2013

Maldonado, T., Alfaro, E. J., Maldonado-Mora, T. J., \& Alfaro-Martínez, E. J. (2010). Comparación de las salidas del modelo MM5v3 con datos observados en la Isla del Coco, Costa Rica. Revista Tecnología en Marcha, 23(4), 3-28. Retrieved from http://revistas. tec.ac.cr/index.php/tec_marcha/article/view/47

Mapes, B. E., Warner, T. T., Xu, M., \& Negri, A. J. (2003). Diurnal Patterns of Rainfall in Northwestern South America. Part I: Observations and Context. Monthly Weather Review, 131(5), 799-812. https:// doi.org/10.1175/1520-0493(2003)131<0799:DPORI $\mathrm{N}>2.0 . \mathrm{CO} ; 2$

Mapes, B. E., Warner, T. T., Xu, M., \& Gochis, D. J. (2004). Comparison of Cumulus Parameterizations and Entrainment Using Domain-Mean Wind Divergence in a Regional Model. Journal of the Atmospheric Sciences, 61(11), 1284-1295. https:// 
doi.org/10.1175/1520-0469(2004)061<1284:COCPA $\mathrm{E}>2.0 . \mathrm{CO} ; 2$

Mass, C. F., Ovens, D., Westrick, K., \& Colle, B. A (2002). Does Increasing Horizontal Resolution Produce More Skillful Forecasts? Bulletin of the American Meteorological Society, 83(3), 407-430. https:// doi.org/10.1175/1520-0477(2002)083<0407:DIHRP $\mathrm{M}>2.3 . \mathrm{CO} ; 2$

Molinari, J., \& Dudek, M. (1992). Parameterization of Convective Precipitation in Mesoscale Numerical Models: A Critical Review. Monthly Weather Review, 120(2), 326-344. https://doi. org/10.1175/1520-0493(1992)120<0326:POCPIM> 2.0.CO;2

Murphy, A. H. (1988). Skill scores based on the mean square error and their relationships to the correlation coefficient. Monthly Weather Review, 116, 2417-2424.

Oglesby, R., Rowe, C., Grunwaldt, A., Ferreira, I., Ruiz, F., Campbell, J., ... Perez, J. (2016). A High-Resolution Modeling Strategy to Assess Impacts of Climate Change for Mesoamerica and the Caribbean. American Journal of Climate Change, 5(2), 202-228. https://doi.org/10.4236/ajcc.2016.52019

Pan, H. L., \& Wu, W. S. (1994). Implementing a mass flux convection parameterization package for the NMC medium-range forecast model. Oregon, USA: American Meteorological Society.

Peña, M., \& Douglas, M. W. (2002). Characteristics of Wet and Dry Spells over the Pacific Side of Central America during the Rainy Season. Mon. Wea. Rev., 130, 3054-3073, https://doi.org/10.1175/1520$0493(2002) 130<3054: \mathrm{COWADS}>2.0$. $\mathrm{CO} ; 2$

Pierce, D. W., Barnett, T. P., Santer, B. D., \& Gleckler, P. J. (2009). Selecting global climate models for regional climate change studies. Proceedings of the National Academy of Sciences, 106(21), 8441-8446. https:// doi.org/10.1073/pnas.0900094106

Pleim, J. E., \& Xiu, A. (1995). Development and Testing of a Surface Flux and Planetary Boundary Layer Model for Application in Mesoscale Models. Journal of Applied Meteorology, 34(1), 16-32. https://doi. org/10.1175/1520-0450-34.1.16

Poveda, G., \& Mesa, O. J. (2000). On the existence of Lloró (the rainiest locality on Earth): Enhanced ocean-land-atmosphere interaction by a low-level jet. Geophysical Research Letters, 27(11), 1675-1678. https://doi.org/10.1029/1999GL006091

Qian, J. H., Seth, A., \& Zebiak, S. (2003). Reinitialized versus Continuous Simulations for Regional Climate Downscaling. Monthly Weather Review, 131(11), 2857-2874. https://doi.org/10.1175/15200493 (2003)131<2857: R V C S F R > 2. 0 . $\mathrm{CO} ; 2$
Quesada-Montano, B. (2011). Historical Daily Precipitation Patterns for Central America Generated Using Constructed Analogues from Satellite and GroundBased Observations. Uppsala, Sweden: Uppsala, University.

Quirós-Badilla, E., \& Hidalgo-León, H. G. (2016). Variabilidad y conexiones climáticas de la zona de convergencia intertropical del Pacífico este. Topicos Meteorologicos y Oceanograficos, 15(1), 21-36.

Rivera, E. R., \& Amador, J. A. (2009). Predicción estacional del clima en Centroamérica mediante la reducción de escala dinámica. Parte II: aplicación del modelo MM5V3. Revista de Matemática: Teoría y Aplicaciones, 16(1), 76-104. Retrieved from http://revista. emate.ucr.ac.cr/index.php/revista/article/view/198/

Schultz, D. M., Bracken, W. E., \& Bosart, L. F. (1998). Planetary- and Synoptic-Scale Signatures Associated with Central American Cold Surges. Monthly Weather Review, 126(1), 5-27. https://doi. org/10.1175/1520-0493(1998)126<0005:PASSSA >2 $.0 . \mathrm{CO} ; 2$

Schultz, D. M., Bracken, W. E., Bosart, L. F., Hakim, G. J., Bedrick, M. A., Dickinson, M. J., \& Tyle, K. R. (1997). The 1993 Superstorm Cold Surge: Frontal Structure, Gap Flow, and Tropical Impact. Monthly Weather Review, 125(1), 5-39. https://doi. org/10.1175/1520-0493(1997)125<0005:TSCSFS $>2$ $.0 . \mathrm{CO} ; 2$

Skamarock, W. C., Klemp, J. B., Dudhia, J., Gill, D. O., Barker, D. M., Duda, M. G., ... Power, J. G. (2008). A Description of the Advanced Research WRF Version 3. Colorado, USA: Mesoscale and Microscale Meteorology Division, National Center for Atmospheric Research.

Srinivasan, J., \& Smith, G. L. (1996). Meridional Migration of Tropical Convergence Zones. Journal of Applied Meteorology, 35(8), 1189-1202. https://doi. org/10.1175/1520-0450(1996)035<1189:MMOTCZ> 2.0. $\mathrm{CO} ; 2$

Stensrud, D. J., Gall, R. L., Mullen, S. L., \& Howard, K. W. (1995). Model Climatology of the Mexican Monsoon. Journal of Climate, 8(7), 1775-1794. https:// doi.org/10.1175/1520-0442(1995)008<1775:MCOT $\mathrm{MM}>2.0 . \mathrm{CO} ; 2$

Taylor, M. A. M. A., \& Alfaro, E. J. (2005). Central America and the Caribbean, Climate of. In J. E. Oliver (Ed.). Encyclopedia of World Climatology (pp. 183189). Netherlands: Springer. Retrieved from http:// dx.doi.org/10.1007/1-4020-3266-8 37

Trenberth, K. E. (2010). Climate System Modeling. New York, USA: Cambridge University Press. Retrieved from http://books.google.se/ books?id=EDClFW7JWrQC 
Wang, C. (2007). Variability of the Caribbean Low-Level Jet and its relations to climate. Clim Dyn, 29, 411. https://doi.org/10.1007/s00382-007-0243-z

Wang, C., \& Enfield, D. B. (2001). The Tropical Western Hemisphere Warm Pool. Geophysical Research Letters, 28(8), 1635-1638. https://doi. org/10.1029/2000GL011763

Wang, C., \& Enfield, D. B. (2003). A Further Study of the Tropical Western Hemisphere Warm Pool. Journal of Climate, 16(10), 1476-1493. https://doi. org/10.1175/1520-0442(2003)016<1476:AFSOTT $>2$ $.0 . \mathrm{CO} ; 2$

Wang, C., Lee, S.-K., \& Enfield, D. B. (2008). Climate Response to Anomalously Large and Small Atlantic Warm Pools during the Summer. Journal of Climate, 21(11), 2437-2450. https://doi. org/10.1175/2007JCLI2029.1

Wang, W., \& Seaman, N. L. (1997). A Comparison Study of Convective Parameterization Schemes in a Mesoscale Model. Monthly Weather Review, 125(2), 252-278. https://doi.org/10.1175/15200493 (1997) $125<0252$ : A C S O C P $>2$. 0 . $\mathrm{CO} ; 2$

Warner, T. T. (2010). Numerical Weather and Climate Prediction. New York, USA: Cambridge University Press. https://doi.org/10.1017/CBO9780511763243

Warner, T. T., \& Hsu, H.-M. (2000). Nested-Model Simulation of Moist Convection: The Impact of Coarse-Grid Parameterized Convection on Fine-Grid Resolved Convection. Monthly Weather Review, 128(7), 2211-2231. https://doi.
org/10.1175/1520-0493(2000)128<2211:NMSOMC $>2.0 . \mathrm{CO} ; 2$

Washington, W. M., \& Parkinson, C. L. (2005). An Introduction To Three-Dimensional Climate Modeling. University Science Books, 372 pp.

Waylen, P. R., Caviedes, C. N., \& Quesada, M. E. (1996). Interannual Variability of Monthly Precipitation in Costa Rica. J. Climate, 9, 2606-2613, https://doi. org/10.1175/1520-0442(1996)009<2606:IVOMPI $>2$ $.0 . \mathrm{CO} ; 2$

Wilks, D. S. (2011). Statistical Methods in the Atmospheric Sciences, Volume 100, Third Edition (3 edition). Boston, USA: Academic Press. Retrieved from http:// www.amazon.com/Statistical-Atmospheric-SciencesInternational-Geophysics/dp/0123850223/ref=sr 11 ?ie $=$ UTF 8 \&qid $=1439990822 \& \mathrm{sr}=8-1 \&$ keywords $=-{ }_{\text {wi }}$ $1 \mathrm{ks}+$ statistical + methods

Xiu, A., \& Pleim, J. E. (2001). Development of a Land Surface Model. Part I: Application in a Mesoscale Meteorological Model. Journal of Applied Meteorology, 40(2), 192-209. https://doi. org/10.1175/1520-0450(2001)040<0192:DOALSM> 2.0.CO;2

Zárate-Hernández, E. (2013). Climatología de masas invernales de aire frío que alcanzan Centroamérica y el Caribe y su relación con algunos índices Árticos. Tópicos Meteorológicos y Oceanográficos, 12(1), $35-55$.

Zárate-Hernández, E. (2014). Influencia de las masas invernales de aire frío sobre el Chorro de Bajo Nivel del Caribe y sus ramas. Tópicos Meteorológicos y Oceanográficos, 13(2), 19-40. 